\title{
Population regulation in large northern herbivores: evolution, thermodynamics, and large predators ${ }^{1}$
}

\author{
By W. T. FluEck, Bariloche
}

\section{Introduction}

Understanding population regulation of large northern herbivores, particularly cervids, has important practical and theoretical implications. Many cervid species have reached very high densities in modern times resulting in a variety of problems. In countless occasions, human intervention was ultimately the last resort to contain herbivore numbers at a certain relationship with the vegetation. This necessity to employ methods of population reduction, however, is only found in man-modified environments, yet the theoretical basis of population regulation continues to be strongly debated (ESTES, 1996). On the one hand it is claimed that large northern herbivores can have a positive influence over their food resources including actively managing it to their benefit as well as exhibiting capacity to adjust their numbers to food supply through a variety of mechanisms (bottom-up regulation, Fig. 1 a). On the other hand, large herbivores are considered incapable of self-regulation and hence that they need external factors like predation to achieve effective population regulation (top-down regulation, Fig. 1 b).

In analyzing population regulation of northern cervids, it is essential to distinguish between natural situations where the pristine framework of interspecific relationships is still intact, and those that are not. Moreover, others cautioned that these relationships in temperate zones are different from tropical environments (MOROWITZ, 1968: 136; GAILLARD et al., 1998; AUGUSTINE and MCNAUGHTON, 1998). The present analysis is based on ecosystems in temperate zones with plants, large herbivores like cervids, and large predators. Firstly, I will argue that existence of density-dependent self-regulation in herbivores has been claimed but not been proven; secondly that thermodynamic and nutrient cycle considerations speak for a system of top-down regulation; and thirdly I will present evidence supporting the existence of functional top-down regulation.

\section{The acclaimed but unproven existence of density-dependent self-regulation in large northern herbivores:}

\subsection{What is the question to be asked?}

Natural self-regulation in northern cervid populations is claimed to be an evolutionary strategy to cope with shortage of resources. The common usage of this concept falls into 3 categories: a) active mechanisms such as territoriality; b) strategies such as reducing reproductive rate when sensing diminished food resources; and c) limits determined by resource availability. The latter 2 categories, however, are often used loosely and in confusion.

\footnotetext{
'Eingesetzt wurde ein Druckkostenzuschuss des Bayerischen Staatsministeriums für Ernährung, Landwirtschaft und Forsten, für dessen Gewährung verbindlich gedankt wird. - Die Schriftleitung.
} 


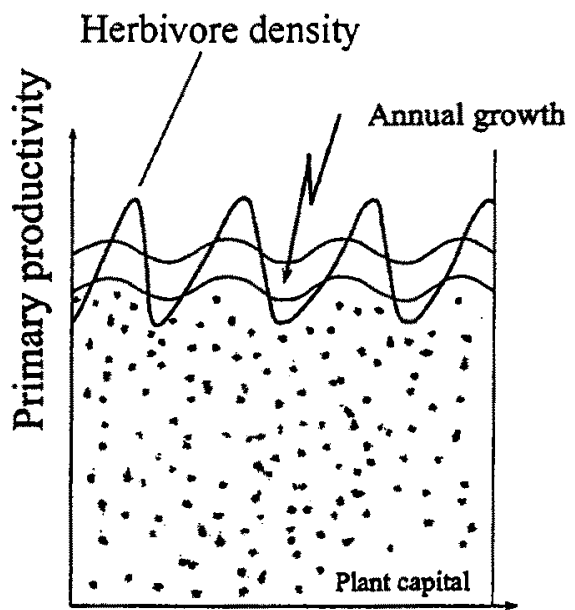

a)

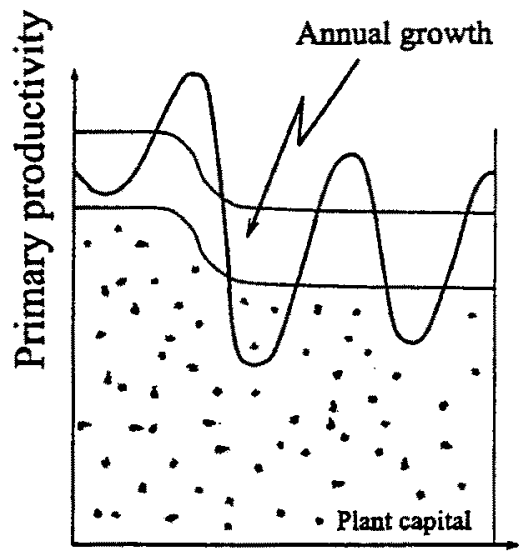

c)

Time

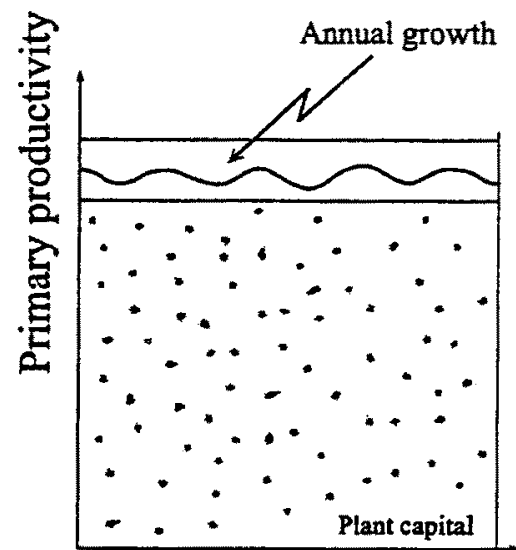

b)

Time

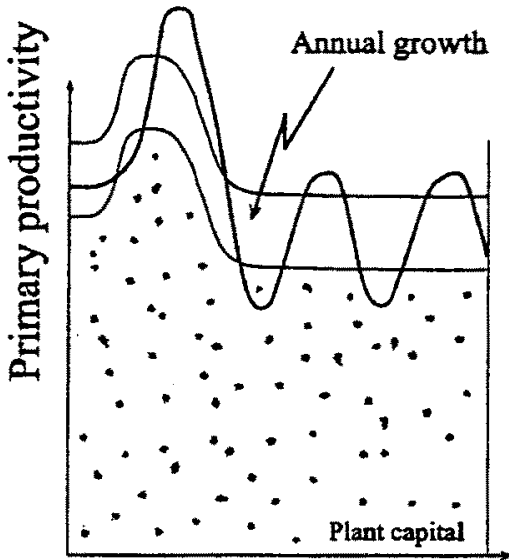

d)

Time

Fig. 1.

a) Plant capital remains stable, most annual growth is removed by herbivores. This would be expected if herbivores exhibit self-regulation or bottom-up regulation.

b) Plant capital remains stable, annual growth is partly removed by herbivores. This would be expected if herbivore populations are regulated by predators.

c) Predators are reduced/removed and herbivores undergo an irruption followed by population crash. Although the system stabilizes at some point, plant capital and annual growth is reduced, and herbivore populations undergo continued irruptions and crashes but at reduced amplitudes. Biodiversity would be lower than in Fig. 1 a).

d) Accessible plant capital and/or annual growth is increased (e.g. through immissions, logging), herbivore populations increase even with predators present and undergo irruptive cycles. Plant capital and annual growth may still remain high initially due to altered dynamics of mineral cycles. 
In essence, "natural" population regulation sensu e.g. SINGER et al., 1997, 1998 occurs in all mammals and represents the third category above. Physiological responses are very similar among different cervids. Thus, parallel to continued population growth, per capita amount of food deprivation increases over several generations allowing for several adaptions to occur, including a decrease in body size. Under more overt conditions, females loose offspring more often and earlier, or directly skip reproductive cycles. Although measurable effects, they have little consequence for population development and merely slow down intrinsic rates of population increase. However, as average body condition deteriorates further, the combined decrease in recruitment rate and increase in morbidity and mortality may result in a population growth rate oscillating around zero, assuming the forage base stabilizes also. If further food deprivation occurs, then it leads to increased death rates and a reduction in population size. This scenario appears to apply to all mammals deprived of food and therefore, this type of "natural regulation" is a maxim. I do not see the value of trying to prove that food deprivation as a result of increased population density is the underlying mechanism of so-called natural self-regulation in cervids. First, the extent of food deprivation is in itself density-dependent. Second, parallel to declining food availability are declining biological parameters (Fig. 2) to a threshold delineated by death. Many studies though have evaluated the supposed density-dependent population regulation of cervids and have concluded that it exists because of the declining biological parameters at high density (CluTTON-BROCK et al., 1982; BERGERUd et al., 1983 a; SingER et al., 1997, 1998; ALBON et al., 1998). "Natural population regulation" through food deprivation, caused by increasing animal density and thus density-dependent, exists without a doubt. Self-regulation on the other hand, as opposed to "regulation" imposed by lack of food, can be viewed from the perspective of herbivores which would imply that individuals detect declining per capita food availability, then exhibit adaptive behavior to counter this tendency such as voluntary restriction of reproductive output, increased territoriality, etc. In this case the animal would have to respond physiologically and behaviorally to a reduced forage base such that herbivore pressure on vegetation does not exceed the upper boundary where vegetation communities would change basic characteristics and thereby change the whole ecosystem. While this view implies evolutionary processes, the commonly deduced existence of "natural regulation" among northern herbivores is not an evolutionary phenomenon and is an artefact of the unnatural setting in which it was studied. As a consequence, the unnatural but stabilized system of vegetation and food-limited large herbivores has been referred to as carrying capacity (RINEY, 1964; CAUGHLEY, 1970; MCCULLOUGH, $1997)$. For this discussion I call it maximum carrying capacity $(K)$ which is the number of herbivores in a stabilized habitar determined by limiting food resources. It also is the underlying concept in formulating the hypothesis that food resources regulate populations of large herbivores (bottom-up control). However, any definition of carrying capacity in a ecologically complete system must imply not only a long-term stability of herbivore and vegetation biomass, but also predator numbers and community species composition; that is, biodiversity should be optimal (SINCLAIR, 1997; SOULE and TERBORGH, 1999). This may be termed evolutionary carrying capacity.

There are no living organisms which can escape the density-dependent effects of decreasing per capita energy availability. The question is not, if evolution produced density-dependent changes on parameters affecting population growth rate, rather if the animal evolved a strategy of self-regulation. Considering this, we need to debate if the phenomenon of superabundant large herbivores like cervids represents the natural state or not. 


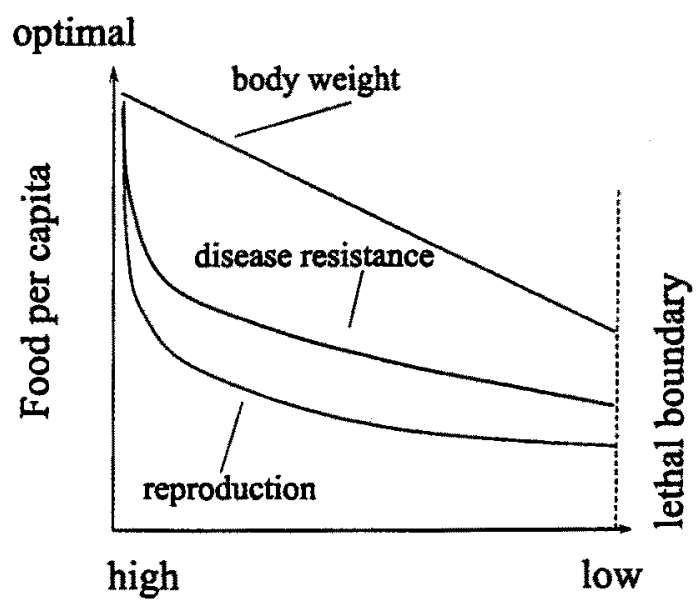

Fig. 2.

Relationships between per capita food availability and body weight, disease prevalence, and reproductive rate.

\section{Biological parameters}

\subsection{Statistical requirements to prove density-dependence}

Existence of density-dependent relationships between limited food supply and a growing consumer population is a basic ecological maxim. It would appear therefore, to be relatively easy to demonstrate in large herbivore populations, especially as there is only one independent variable, namely per capita food availability. Nonetheless, several authors have questioned if this phenomenon has been proven to exist in cervids. WHITE and BARTMANN (1997) stated that most studies were in man-modified situations and many were flawed by incorrect analysis and conclusions. None of the major studies concluding that densitydependence occurs had adequate replications to make inferences widely applicable or used published tests for density dependence. However, even if proven to exist, it remains to be demonstrated that it is relevant in natural ecosystems not yet modified by man.

The situation is even more complicated when trying to show predation as a densitydependent mechanism for herbivore population control under pristine conditions. If it is not already extremely difficult to show density-dependence for the simplistic food-herbivore system, it is a daunting problem to show for a predator-herbivore system. The logistics are extremely unfavorable because densities of study populations are very low; large systems not yet man-modified are practically absent; generation intervals of study objects requires long-term studies much longer than career lengths of researchers; and replications would be necessary, to name a few limitations.

Predator-prey studies to date were most commonly done in man-modified environments (Peterson, 1988; Boutin, 1992; Gaillard et AL., 1998). Kay (1997 a) for instance, shows that most of North America might have been substantially modified by aboriginal hunting and use of fire before Columbus. Similarly, the Swiss National park and surroundings have received heavy resource use for at least 5000 years (ZOLLER, 1993) as was the case for many other areas in Europe. Thus, either habitat had been altered significantly (ANDERSON et al., 1992), predator or prey communities were incomplete (PETERSON, 1988; FULLER, 1989; BREITENMOSER and HALLER, 1993; LINDZEY et al., 1994; SiNGER et al., 1997, 1998; GRENFELL et al., 1998; BALLARD et al., 1999), or predator and prey populations were subjected to hunting (FULLER, 1989; BOUTIN, 1992; GASAWAY et al., 1992; BALLARD et al., 1997; KUNKEL and PleTSCHER, 1999), or combinations of these factors. Furthermore, the effect 
of usually one predator on one prey species was evaluated when in reality there were several predator and prey species present, and relationships remained unclear (FULLER, 1989; HugGard, 1993 a; SCHAEFer et al., 1999) as is to be expected (WEBER et al., 1989). Previous studies to determine existence of functional responses by predators failed to prove it due to inadequate power of their study design (BOUTIN, 1992; MARSHAL and BOUTIN, 1999). Moreover, due to high variability encountered in natural systems it is unlikely that traditional predator-prey studies can determine functional response and hence, regulation through predation, particularly because human activities have greatly affected the degree of these variations. Previous studies were largely inadequate to show density-dependent population regulation through predation and there are severe practical constraints to do so in the future.

\section{Thermodynamics and nutrient cycles}

HAIRSTON et al. (1960) made three generally accepted observations: bound energy is fossilized at an ecologically insignificant rate; most organic matter produced by terrestrial plants falls to the ground uneaten; and when large herbivores are subjected either to removal of predators or to being introduced into regions which their predators have not reached, they frequently become numerous enough to deplete the vegetation. From these observations, they have shown that as whole groups, terrestrial decomposers, producers and predators are limited by their own depletion of their respective resources, whereas terrestrial herbivores must be limited in abundance by predation and parasitism. They further concluded that communities with herbivore numbers being held down will be the most persistent. These observations have been corroborated by theoretical considerations (see below).

Pristine temperate terrestrial food chains are dominated by plant-herbivore-predator systems. However, bottom-up regulation considers the plant-large herbivore system as the principal evolutionary development that determines plant-herbivore dynamics while large predators are mere luxury expressions of evolutionary diversity, but with no direct influence over trophic interaction between plants and large herbivores. The theory of top-down regulation on the other hand considers large predators as a primary evolutionary development with dominant impact on dynamics of all lower trophic levels. Evolutionary theory thus has the potential to shed light on these two views on regulation of large herbivores in temperate zones. It is the necessity to explain the functional roles which requires a change from mechanistic explanations to one based on the concept of patterns of informed energy flow in open systems far from equilibrium which currently best accounts for complexity observed in temperate plant-large herbivore-large predator systems (HAIRSTON, 1964; ULANOWICZ and ABARCA-ARENAS, 1997). The description of such systems is inherently thermodynamic in nature and as such the second law of thermodynamics plays a central role.

The earth accumulates insignificant amounts of energy over evolutionary time and thus represents a steady state system, where flux of solar radiation is balanced by loss of energy to outer space (HAIrSTON et al., 1960; MOROwITZ, 1968). Although this has been recognized previously, the Second Law of Thermodynamics was restated only recently to allow for a complete description of living processes (SCHNEIDER, 1988; WEBER et al., 1989; UlANOWICZ, 1996, 1999; UlANOWICZ and ABARCA-ARENAS, 1997; KAY, 2000). MOROWITZ (1968) has shown that flow of exergy through a system will lead to cycling of both energy and materials in that system, i. e. spontaneous formation of dissipative structures. This theorem of MOROWITZ also applies to complex living systems. Such cyclicity not only 
allows systems to develop stability but to develop structure and hierarchy within them. Thus, earth being an open thermodynamic system experiencing a continuous gradient of exergy may explain self-organization to reduce this imposed gradient, which resulted in progressive irreversible physical, chemical autocatalytic, and biological evolution to extant sophisticated energy degrading chains (see also GOULD, 1989). During the development of an open system, it exhibits a propensity to go toward optimum order and optimum accumulation of energy (MOROWITZ, 1968; WEBER et al., 1989; ODUM, 1991) which has been quantified by the concept of system ascendency (ULANOWICZ and ABARCA-ARENAS, 1997; ULANOWICZ, 1997). This growth principle with its propensity of irreversible directionality is a fundamental feature of thermodynamic processes, evolution, degree of biodiversity and ecosystem complexity (LOTKA, 1925; ODUM and PINKERTON, 1955; DEANGELIS, 1992, SHANAHAN, 2000). As a result, if an ecosystem is allowed to mature, it follows a repeatable sequence of species composition (constrained by historical events), that is, entropy constrains the direction that natural processes take (SCHNEIDER, 1988). It explains evolution of ecomorphs, which are similar phenotypes stemming from unrelated taxa, like marsupial and placental ecomorphs. Sabel-toothed predators re-evolved on five separate occasions during 38 million years (placental and marsupial) and it also explains the increase in predator diversity since the Tertiary (MARTIN, 1989; HUNT 1996). When feeding niches requiring certain predatory strategies were available, different taxa could occupy them depending which other taxa were present at the time, indicative of systemic functional responses. Strategies varied from cursorial pursuit hunting occurring in the past among marsupial "wolves", bears, hyenas to social hunting in bears and hyenas, to stalk-andambush hunting among marsupials, hyenas (with retractable claws), canids, mustelids resembling leopards in size and skull form, as well as extinct beardogs, nimravids, and creodonts (MARTIN, 1989; HUNT, 1996; WERDELIN, 1996).

So how does thermodynamic irreversibility relate to northern plant-herbivore-predator systems? First, non-equilibrium thermodynamics and the theorem of MOROWITZ predict evolutionary direction of optimal order and optimal accumulation of energy and nutrients. The existence of large predators is thus the direct expression of these predictions, and the system as a whole, in its pristine condition, expresses optimal order and accumulation of energy and nutrients (species assemblage with most efficient capture and retention of radiant energy). The same conclusion is reached when considering nutrient cycles and food webs (DEANGELIS, 1992). This is no surprise because the expression of the non-equilibrium thermodynamic principle by organisms requires their parallel optimization of nutrient incorporation. This explains why, as ecosystems become more efficient and most nutrients become recycled internally, the pool of nutrients stored in biomass becomes larger while the nutrient pool in soil becomes increasingly reduced compared to the biomass (ODUM, 1991; DEANGELIS, 1992). In fact, mineral release from weathering of rock is insignificant in relation to what the maximal standing biomass needs and thus, mature forest systems may take thousands of years to develop through increasing biogeochemical cycling efficiency (DEANGELIS, 1992). Minerals like selenium become extremely compartmentalized until most bioavailable forms are in biomass (FLUECK and SMITH-FLUECK, 1990). Stressinduced leaky ecosystems can subsequently affect mammalian species and thereby trophic dynamics (FLueCK, 1990; DEANGELIS, 1992; FlueCK, 1994 a). As most nutrients were tied up in north-temperate forests as standing biomass, plus little light reaching the ground, there was little and slow growth of forage plants which resulted in low density of cervids consuming only a small fraction of forest biomass. Although large herbivores can positively influence their food supply in several ways (GORDON and LINDSAY, 1990), based on thermodynamics this capacity is limited and does not influence the overall relationship between vegetation and herbivores. However, predators can cause shorter generation inter- 
vals and lower density in prey and rates of nutrient cycling are increased substantially, both in primary and secondary producers. Predators might thus maximize the efficiency of conversion of radiant energy into their own biomass by controlling prey turnover time and thereby rate of nutrient cycling, as predicted by non-equilibrium thermodynamics. Without large predators (or with anthropogenic shifts in nutrient cycles), cervid populations increase until limited by food availability. At these densities, cervids reduce biodiversity, plant biomass, photosynthetic rates, and render the system leaky. Reduction of photosynthetic capacity not only increases atmospheric $\mathrm{CO}_{2}$, but eliminates heat dissipation through transpiration which may contribute to global warming by one to two orders of magnitude more than $\mathrm{CO}_{2}$ (SCHNEIDER and KAY, 1994).

\section{Evidence for top-down regulation}

\subsection{Evolutionary traits in line with thermodynamic irreversibility}

Co-evolution between large predators and their prey is unlikely as they are characterized by asymmetrical selection precluding co-evolutionary arms races (VERMEIJ, 1994; BRODIE and BRODIE, 1999). Interactions are complex because most predators prey on several species, while most herbivores are facing several predator species. Herbivores experience more selection pressure than predators which are able to avoid selection imposed by herbivores (BRODIE and BRODIE, 1999). Furthermore, adaptations and co-adaptations cannot evolve to infinitely greater values since there are many biological and morphological constraints that limit evolutionary responses; this explains why re-evolved traits are so convergent in design even among distant phylogenetic line (i. e. placental versus marsupial). Predators thus tend to be generalists adapted to prey switching, thereby alleviating selection pressure from any single prey. Stalking predators for instance, appear to be non-selective and kill the unwary (JOBIN et al., 1999). VERMEIJ (1994) argues that predators experience selection pressure through their own predators or competitors. Evolutionary change in predators therefore, is not driven by their prey.

Almost all modern Carnivora result from radiations having taken place during the last seven million years with a clear overall increase in carnivore diversity since the Tertiary (MARTIN, 1989). Several top-level predators are or were features of every temperate ecosystem (MCLAREN and PETERSON, 1994; EsTES, 1996). Single predator systems only exist now because other large predator species were hunted to extinction (GASAWAY et al., 1992). Wolves (Canis lupus) were the most widespread predator (PETERSON, 1988) before being extirpated from much of their historic range (PLETSCHER et al., 1997). Northern large herbivores, therefore, are adapted to the presence of predators and evolution has shaped their anatomy, behavior and senses to avoid such predators (WILCOX and MACCLUER, 1979; EDWARDS, 1983; FRYXELL, 1991; FRID, 1997). To account for predator-avoidance features, presence of predators must have been a predominant factor in the evolutionary ecology of northern herbivores. The "natural state" thus implies continued presence of predators. A well-studied sequence of a predator guild over a 12 million year span showed a steady richness of predator species and their patterns of resource division remained stable, probably reflecting interspecific competition (MARTIN, 1989; VAN VALKENBURGH, 1995). Temporary absence of a predator may occur (e.g. disease), but a local vacuum would readily be replaced by immigrant predators (LINDZEY et al., 1992, 1994). In multi-predator systems, temporary disappearance of one predator could partially be compensated for by other species such as through meso-predator release phenomena (THURBER and PETERSON, 1991; ESTES, 1996). Predators exhibit strategies like territoriality, prey switching, and intra- and inter- 
specific aggression, and thereby regulate their own and prey populations. In contrast, herbivores can only be self-regulating by exhibiting territoriality, both intra- and interspecifically (GORDON and LINDSAY, 1990). Nonetheless, there is no evidence that this behavior has evolved in temperate herbivores like cervids.

\subsection{Ecological traits of large northern predators}

Cervids provide a relatively stable food source for numerous predator species. Wolves are primary predators of cervids and occurred throughout the northern hemisphere together with brown bear (Ursus arctos), lynx, bobcats (Lynx rufus) and wolverine (Gulo gulo). Other predators like the other ursids, puma (Puma concolor), and coyote (Canis latrans) were limited to particular continents. Effects of different predator species are additive on herbivores due to different hunting strategies (PETERSON, 1988; KUNKEL and PLeTSCHER, 1999). Large predators can regulate herbivores if they intrinsically regulated themselves, and if there is alternative prey (ERLINGE et al., 1984). Social systems consist of territoriality (KEITH, 1974; GORMAN and TROWBRIDGE, 1989; SANDELL, 1989) separating either individuals or social group units in time and space: wolves (FULLER, 1989; LEWIS and MURRAY, 1993), brown bear (WIELGUS and BUNNELL, 1994), black bear (Ursus americanus) (KEITH, 1974), lynx (KerTH, 1974; BeLTRAN et al., 1992; BREITENMOSER and HALLER, 1993), bobcats (BAILEY, 1974), wolverine (BJARVAll et al., 1996), puma (SEIDENSTICKER et al., 1973; HORNOCKER and BAILEY, 1986; SPREADBURY et al., 1996), foxes (KeITH, 1974) and coyote (HARrison and HARrison, 1984; PYraH, 1984; SACKS et al., 1999). Territory pattern formation in wolves has been shown to be a stable phenomenon which also provides buffer zones for prey (FULLER, 1989; TAYLOR and PEKINS, 1991; LEWIS and MURRAY, 1993).

Table 1. Home range sizes $\left(\mathrm{km}^{2}\right)$ encountered for various large predators. Home ranges of males and females often overlap.

\begin{tabular}{|c|c|c|c|c|}
\hline & male & female & both sexes & citation \\
\hline Puma & $\begin{array}{l}221-938 \\
179-826 \\
453 \\
151\end{array}$ & $\begin{array}{l}98-574 \\
59-685 \\
173-306 \\
55\end{array}$ & & $\begin{array}{l}\text { ANDERSON et al., } 1992 \\
12 \text { studies cited in } \\
\text { ANDERSON et al., } 1992 \\
\text { SEIDENSTICKER et al., } 1973 \\
\text { SPREADBURY et al., } 1996\end{array}$ \\
\hline Lynx & 10 & 10 & 10 & $\begin{array}{l}\text { BELTRAN et al., } 1992 \\
\text { CHAMBERLAIN et al., } 1999\end{array}$ \\
\hline Wolverine & $\begin{array}{l}150-400 \\
422 \\
535\end{array}$ & $\begin{array}{l}150-400 \\
100 \\
105\end{array}$ & & $\begin{array}{l}\text { BJARVALL et al., } 1996 \\
\text { HORNOCKER and HASH, } 1981 \\
\text { WHITMAN et al., } 1986\end{array}$ \\
\hline Brown bear & 768 & 125 & & MACE and WALLER, 1997 \\
\hline
\end{tabular}

Home range size and density are largely determined by food supply, although with possible time lags as shown for lynx (BREITENMOSER and HALLER, 1993; POOLE, 1994; OKARMA et al., 1997), wolf (FULLER, 1989; DANILOV, 1990; GASAWAY et al., 1992) and bear (SCHWARTZ and FRANZMANN, 1991; ADAMS et al., 1995). Variations of home range size and population density indicate great flexibility of predators to adjust to food supply (Table 1 and 2). GaSAwAY et al. (1992) found that wolf and brown bear remained effective when moose (Alces alces) density was very low, and they did not go extinct even when there was 
no alternative prey. However, there is an intrinsic upper limit of density determined by social mechanisms and further increased herbivore densities do not illicit a higher predator densities (LinDZEY et al., 1994; PLETSCHER et al., 1997). Daily movements also vary with prey density, and puma have been shown to travel 43 linear $\mathrm{km}$ in 9 hours (ANDERsON et al., 1992).

Table 2. Density of large predators per $100 \mathrm{~km}^{2}$ : different species cited in the same paper often occurred together.

\begin{tabular}{|c|c|c|c|}
\hline & density & citation & comments \\
\hline Puma & $\begin{array}{l}7 \\
3.7 \\
3-4 \\
3 \\
1.4 \\
1.1 \pm 0.15\end{array}$ & $\begin{array}{l}\text { KUNKEL et al., 1999; } \\
\text { KUNKEL and PLETSCHER, } 1999 \\
\text { SPREADBURY et al., } 1996 \\
\text { ANDERSON et al., } 1992 \\
\text { HORNOCKER, } 1970 \\
\text { LINDZEY et al., } 1994 \\
\text { ANDERSON et al., } 1992\end{array}$ & $\begin{array}{l}\text { hunted population } \\
\text { unhunted population } \\
\text { hunted population }\end{array}$ \\
\hline Wolf & $\begin{array}{l}1.6-11.6 \\
8 \\
4 \\
3.3-4.5 \\
3.5 \\
3 \\
2.3 \\
1.7 \\
1.5 \\
1 \\
0.6-1.5 \\
0.5 \\
0.2-0.8 \\
0.15\end{array}$ & $\begin{array}{l}\text { REIG et al., } 1992 \\
\text { STEPANOV and POLE, } 1996 \\
\text { KEITH, 1974 } \\
\text { FULLER, 1989 } \\
\text { PLETSCHER et al., } 1997 \\
\text { PECHACEK, } 1994 \\
\text { BALLARD, } 1992 \\
\text { CARBYN, } 1983 \\
\text { PECHACEK, } 1994 \\
\text { KUNKEL et al., 1999; } \\
\text { KUNKEL and PLETSCHER, } 1999 \\
\text { BALLARD et al., 1997 } \\
\text { GASAWAY et al., } 1992 ; \\
\text { ADAMS et al., } 1995 \\
\text { DANILOV, } 1990 \\
\text { ZHELEZNOV, } 1992\end{array}$ & $\begin{array}{l}\text { maximal density } \\
\text { legal and illegal harvests } \\
\text { unhunted population } \\
\text { hunted population } \\
\text { recently recolonizing } \\
\text { heavily hunted population }\end{array}$ \\
\hline Brown bear & $\begin{array}{l}1-55 \\
6.4 \\
4-6 \\
4 \\
3 \\
\\
2.8 \\
2-3 \\
0.2\end{array}$ & $\begin{array}{l}\text { MLLLER et al., } 1997 \\
\text { KUNKEL et al., 1999; } \\
\text { KUNKEL and PLETSCHER, } 1999 \\
\text { DANILOV, } 1990 \\
\text { SCHMIDT and GILBERT, } 1978 \\
\text { ADAMS et al., 1995; } \\
\text { ZHELEZNOV, 1996 } \\
\text { BALLARD, 1992 } \\
\text { MACE and WALLER, } 1997 \\
\text { GASAWAY et al., 1992 }\end{array}$ & $\begin{array}{l}\text { hunted population } \\
\text { hunted population }\end{array}$ \\
\hline Black bear & $\begin{array}{l}39 \\
38 \\
9-29 \\
20\end{array}$ & $\begin{array}{l}\text { KEITH, } 1974 \\
\text { SCHMIDT and GILBERT, } 1978 \\
\text { MILLER et al., } 1997 \\
\text { KUNKEL et al., 1999; } \\
\text { KUNKEL and Pletscher, } 1999\end{array}$ & $\begin{array}{l}\text { hunted population } \\
\text { hunted population }\end{array}$ \\
\hline Lynx & $\begin{array}{l}44.9 \\
30 \\
20\end{array}$ & $\begin{array}{l}\text { SLOUGH and MOWAT, } 1996 \\
\text { POOLE, } 1994 \\
\text { PARKER et al., } 1983\end{array}$ & $\begin{array}{l}\text { high of cycle } \\
\text { high of cycle } \\
\text { low of cycle }\end{array}$ \\
\hline
\end{tabular}




\begin{tabular}{|c|c|c|c|}
\hline & $\begin{array}{l}7.8 \\
3 \\
2.7\end{array}$ & $\begin{array}{l}\text { BERGERUD, } 1971 \\
\text { BUFKA and CERVENY, } 1996 \\
\text { SLOUGH and MOWAT, } 1996\end{array}$ & $\begin{array}{l}\text { after reintroduction } \\
\text { low of cycle }\end{array}$ \\
\hline Coyote & $\begin{array}{l}47 \\
39 \\
14 \\
14\end{array}$ & $\begin{array}{l}\text { KEITH, } 1974 \\
\text { PYRAH, } 1984 \\
\text { KEITH, } 1974 \\
\text { HENKE and BRYANT, } 1999\end{array}$ & $\begin{array}{l}\text { high of cycle } \\
\text { hunted population } \\
\text { low of cycle }\end{array}$ \\
\hline Wolverine & 2 & HORNOCKER and HASH, 1981 & \\
\hline
\end{tabular}

Table 3 indicates the specialization of large northern predators for preying on cervids (also see CARBYN, 1983; HUGGARD, 1993 a, b; BOYD et al., 1994). Brown bear with young were found to kill 6.3 calves per day during calving season (YOUNG and MCCABE, 1997). Other adaptive behavior was shown for wolf switching to other prey when density of their main prey fell below a threshold of 0.2 moose $/ \mathrm{km}^{2}$ (BALLARD et al., 1997). However, prey switching also occurs simply because new food sources become easier to obtain, for instance when calving seasons among different prey are staggered (ADAMS et al., 1995). The entire native carnivore assemblage of Patagonia has switches nearly completely to consuming introduced prey species which now comprise about $95 \%$ of the prey biomass (Novaro et al., 2000). All carnivores appeared to be opportunistic predators selecting prey according to catchability.

Table 3. Specialization of large predators on northern large herbivores.

a) Percent ungulates in diet

\begin{tabular}{|l|l|l|l|l|l|}
\hline & $\begin{array}{l}\text { spring- } \\
\text { summer }\end{array}$ & $\begin{array}{l}\text { fall- } \\
\text { winter }\end{array}$ & annual & prey & citation \\
\hline Lynx & 95 & 90 & 100 & $\begin{array}{l}\text { roe and red deer } \\
\text { ungulates }\end{array}$ & $\begin{array}{l}\text { OKARMA et al., 1997 } \\
\text { BUFKA and } \\
\text { CERVENY, 1996 }\end{array}$ \\
\hline Bobcat & & $28-32$ & & cervids & POLL.ACK, 1951 \\
\hline Wolf & & & $\begin{array}{l}100 \\
100 \\
93 \\
90+\end{array}$ & $\begin{array}{l}\text { red deer } \\
\text { cervids } \\
\text { moose, caribou 4:5 } \\
\text { cervids } \\
\text { ungulates } \\
\text { cervids }\end{array}$ & $\begin{array}{l}\text { BOBEK et al., 1992 } \\
\text { KUNKEL et al., 1999 } \\
\text { BALLARD et al., 1997 } \\
\text { HUSZYNSKA, 1996 } \\
\text { FUGGARD, 1993 a }\end{array}$ \\
\hline FulLER, 1989
\end{tabular}


b) Percent mortality of cervids caused by predators

\begin{tabular}{|c|c|c|c|}
\hline & $\%$ & prey & citation \\
\hline $\begin{array}{l}\text { Brown bear and wolf } \\
\text { Brown bear and wolf } \\
\text { Brown bear and wolf } \\
\text { Brown bear and wolf } \\
\text { Brown bear and wolf } \\
\text { Lynx } \\
\text { Coyote } \\
\text { Coyote } \\
\text { Brown/black bear, } \\
\text { wolf, puma }\end{array}$ & $\begin{array}{l}53 \text { and } 7 \\
58 \text { and } 25 \\
50 \text { and } 26 \\
5-25 \text { and } 15-50 \\
66 \text { and } 17 \\
74 \\
82 \\
79 \\
>90\end{array}$ & $\begin{array}{l}\text { moose calves } \\
\text { moose calves } \\
\text { moose adult }+ \text { calves } \\
\text { moose } \\
\text { moose calves } \\
\text { caribou calves } \\
\text { deer fawns } \\
\text { deer fawns } \\
\text { cervids }\end{array}$ & $\begin{array}{l}\text { BALLARD et al., } 1992 \\
\text { LARSEN et al., } 1989 \\
\text { LARSEN et al., } 1989 \\
\text { DANILOV, } 1990 \\
\text { BALLARD et al., } 1991 \\
\text { BERGERUD, } 1971 \\
\text { KEITH, 1974 } \\
\text { WHITTAKER and } \\
\text { LINDZEY, } 1999 \\
\text { KUNKEL and } \\
\text { PLETSCHER, } 1999\end{array}$ \\
\hline Wolverine & \multicolumn{2}{|c|}{$\begin{array}{l}21-52 \% \text { of all predator losses in reindeer } \\
4-8 \% \text { of all predator losses in moose }\end{array}$} & $\begin{array}{l}\text { FILONOV, } 1980 \\
\text { FILONOV, } 1980\end{array}$ \\
\hline
\end{tabular}

Predator population regulation: Large predator population regulation revolves around territorial, dispersal and social behavior (WASER, 1996). Aggressive behavior increases when food supplies diminish. Intraspecific killing has been documented numerous times including within family units for wolves (PETERSON, 1988; FULLER, 1989), puma (LINDZEY et al., 1988; ANDERSON et al., 1992), lynx (POOLE, 1994), brown bear (SCHMIDT and GilBERT, 1978), black bear (KEITH, 1974) and wolverine (BJARVALL et al., 1996). Replacement of a home range by a new individual is preceded with heavy fighting (BELTRAN et al., 1992).Comparing puma density with and without hunting LINZEY et al. (1994) found no change and concluded that puma remained at carrying capacity through increased immigration. Experimental removal of adult male black bear resulted in a $50 \%$ increase of bear density by eliminating adult male predation on subadults (KEITH, 1974). Interspecific aggression may be underestimated in importance due to difficulty of documentation. KOEHLER and HORNOCKER (1991) showed puma may kill a significant portion of medium sized predator species like bobcats and coyotes ( $63 \%$ and $43 \%$ of mortality, respectively) during times of greater habitat use overlap. Wolves kill and even eliminate coyotes, as on Isle Royal (Peterson, 1988; PAQueT, 1992). This interference competition not only affects population density of other predators, but determines their geographical distribution and hence, distribution in time and space of prey. Interference competition is also inferred throughout evolutionary history of Carnivora (WERDELIN, 1996).

Predator recruitment rate is affected by food supply. Following intense prey population crash, lynx rapidly declined 10 -fold, due principally to an up to $100 \%$ loss of kittens, higher mortality rates for adults and dispersal (POOLE, 1994). Wolves entering new areas with plenty prey increased their reproductive rate by 3 -fold (PECHACEK, 1994) and similarly, density of brown and black bear increased when more prey became available (ADAMS et al., 1995). That large predators can be very prolific is shown by sustained hunting harvest rates of generally over $28 \%$ and up to $60 \%$ for wolves (KEITH, 1974; FULLER, 1989). However, inability of large predators to effectively reduce irruptive herbivore populations in man-modified habitats reflect constraints on functional and numerical responses (KEITH, 1974; FLUECK and SMITH-FLUECK, 1996).

What keeps large predators from reaching densities where they could deplete their prey? At the scale of their distribution, predators of cervids are not food limited to the point of compromising their own existence. Other mechanisms like dispersal (Mech, 1987), prey 
switching (ADAMS et al., 1995; BALLARD et al., 1997), intra- and interspecific killing of predators (HORNOCKER, 1970; SCHMIDT and GILBERT, 1978; SLOUGH and MOWAT, 1996; SPREADBURY et al., 1996; MACE and WALLER, 1997; KUNKEL et al., 1999), reduced fecundity and territoriality prevail. These mechanisms are predicted by relatively stable food sources consisting of long-lived large herbivores. In complex systems, large bodied multi-prey and multi-predators have coexisted for over 12 million years (MARTIN, 1989; VAN VALKENBURGH, 1995).

Effect on herbivore populations: Large predators regulate large herbivores especially at low densities (MECH and KARNS, 1977; CARBYN, 1983; BERGERUD et al., 1983 b; MESSIER and CRETE, 1985; BERGERUD and SNIDER, 1988; BIBIKOW, 1988; MESSIER, 1991; GASAWAY et al., 1992; BreItENMOSER and HALLER, 1993; OKARMA et al., 1997), through a numerical and functional response (MEssier, 1991). Huemul (Hippocamelus bisulcus) of a temperate mixed broad leaved ecosystem coexists with an intact predator community at densities of $0.5-2 / \mathrm{km}^{2}$ when there are no anthropogenic influences like hunting, livestock, or logging (DIAZ and SMITH-FLUECK, 2000). Wolf and bear kept an unhunted moose population below food limitation (MESSIER and CRETE, 1984). Other studies found predation to limit cervid populations (CARBYN, 1983; KUNKEL and PLETSCHER, 1999), while still others concluded that regulation through predators exists at low prey density which in absence of predation would reach another density domain determined by food abundance (BERGERUD et al., 1983 a, b; BERGERUd and SNIDER, 1988; MCLAREN and PETERSON, 1994).

With absence of predation, roe deer (Capreolus capreolus) density was 3 times higher than in presence of lynx (GAROSS, 1979, cited in OKARMA et al., 1997), similar to results with red deer (Cervus elaphus) when wolf disappeared (PECHACEK, 1994). Reintroduced lynx on the other hand diminished prey density by $38 \%$ within 6 years (BREITENMOSER and HALLER, 1993). Extinction of wolf and removal of most lynx resulted in a 24-fold increase in caribou density (Rangifer tarandus) whereas other predator-free caribou herds grew up to 40 -fold over densities encountered in presence of wolves. In these cases the lack of timely intrinsic density-dependent limitations resulted in population crashes (BERGERUD et al., 1983 a). BERGERUD and SNIDER (1988) concluded that density of moose in absence of wolf are approximately 10-fold higher than in their presence. Similarly, MESSIER (1991) and MESSIER and CRETE (1985) found that the wolf regulatory effect was due to their numerical and functional responses at lower cervid density, however, at high density cervid population sizes became unstable. KEITH (1974) reported on a wolf reduction program due to rabies in Alberta where over 5400 wolves were killed; in subsequent years the sale of moose hunting permits increased from 6500 to 50,000 . Reducing bear by $60 \%$ increased recruitment rate of moose and significantly affected their population dynamics and density (BALLARD and MILLER, 1992). Interestingly, only recently have bear been recognized as significant factors affecting survival of young cervids; but even black bear are known to kill adult male wapiti (Cervus elapbus) in good condition (BARMORE and STRADLEY, 1971). Moreover, combinations of several major predators reduced prey species substantially: when only one predator was present, prey density was higher (GASAWAY et al., 1992; KUNKEL et al., 1999). As presented in table 3 , predation can substantially reduce herbivore recruitment and has accounted for $50 \%$ or more of juvenile mortality (ADAMS et al., 1995; BALLARD et al., 1999).

Many authors agree that extrapolating from single predator - single prey studies to multiple prey - multiple predator systems makes interpretation difficult (SCHAEFER et al., 1999). Unfortunately, most predator studies are based on single predator species (LIMA, 1992). Another complicating factor on determining actual effect of large predators on prey is intraspecific variation on killing rate. For instance, increased prey per wolf decreases consumption rates of carcasses (CARBYN, 1983) and effectively, kill rate per wolf increases. 
Although reintroduced lynx initially made multiple kills and reduced consumption per kill, this stopped as the prey density decreased (BREITENMOSER and HALLER, 1993). Furthermore, during a numerical response of predators, reproductive rates are high and females with young increase kill rate by 2-3 times (OKARMA et al., 1997). Large predators also exhibit cultural inheritance and learning capacity and behavior is flexible and dynamic. Therefore, average kill rate per predator is misleading, as it varies according to actual ratios of predators/prey (even seasonally), sex and age distribution of predators, presence and dynamics of other prey and predator species. Meanwhile, as captures per unit time increase with higher prey density, there is a "satiation" threshold, at which point captures per unit time become constant (saturation) (SOLOMON, 1949; ABRAMS, 1993).

Impact of large predators on prey goes beyond kills. Attack success rates are low, like $20 \%$ for lynx (Lynx spp.) (BUFKA and CERVENY, 1996) or $5 \%$ for wolves (HugGARD, $1993 \mathrm{~b}$ ), resulting in many opportunities for prey adaption. Consequently, distribution and habitat use by herbivores and its sequels on vegetation is closely linked to presence and distribution of predators (TERBORGH, 1988; BOWYER et al., 1997). Moreover, predators may drive niche differentiation among herbivores, be it intraspecific differentiation by sex or age, or interspecific differentiation in herbivore communities (EDWARDS, 1983; SKOGLAND, 1991). Predators therefore act as powerful selective force on herbivores' morphology, physiology and behavior, they mediate interspecific competition and thereby enhance community diversity and resilience, and they affect abundance and distribution of herbivores and ultimately composition and dynamics of vegetation (KEITH, 1974; PETERSON, 1988).

Top-level predators act as keystone species influencing community structure profoundly (ESTES, 1996; KunKel et al., 1999; SOUle and TERbORGH, 1999; Henke and BRYANT, 1999). Local extinction of large predators releases meso-predators which were limited before, and their release bears major effects through ecosystems (HENKE and BRYANT, 1999). Reintroductions of large predators results in decreased cervid density. High densities of cervids can eliminate plant and animal species from pristine ecosystems (PUTMAN et al., 1989; DeCALESTA, 1994; BAINES et al., 1994) and threshold densities for cervids can be established above which plant species go extinct (WHITE et al., 1998). For instance, extermination of large predators in Scotland resulted in high density deer population preventing native woodland regeneration for over 200 years, and as trees have reached their limit of seed bearing age, there is the possibility of losing these forests (MAGNUSSON, 1993). Therefore, the presence of large predators is essential in preventing losses of community components which occur in pristine areas.

\subsection{Ecological traits of herbivores}

Lack of behavioral adaptations for self-regulation: Theory and empirical information support the conclusion that most density-dependent change occurs at high population levels (close to $K$ ) for species with life history strategies typical of large mammals, such as cervids (FOWLER, 1981). In artificial environments, white-tailed deer (Odocoileus virginianus) can occur at very high densities (exceeding $75 / \mathrm{km}^{2}$ ), yet still be very healthy with no evidence of stress often associated with high density populations (HANSEN et al., 1997). During an irruption which increased density 24-fold, Bergerud et al. (1983 a) found the population passing through the entire range of densities where intraspecific competition for food was predicted to result in logistic growth. Instead, population crashes occurred with little change in reproductive parameters as expected prior to the decline. When density-dependent changes become effective, significant damage to vegetation has already occurred. Moose at different densities showed that a stable high-density equilibrium between moose and their food resources as expected from the maximum carrying capaci- 
ty hypothesis is unlikely. Predator reduction resulted in an irruption of moose with a fourfold increase in density (GASAWAY et al., 1992) and in absence of large predators it will lead to large fluctuations in moose population size leading to overt impact on vegetation (SAETHER and ANDERSEN, 1996). Moreover, overcrowding resulted in high frequency of bone fractures even in juveniles due to osteoporosis resulting from inadequate nutrition (YTREHUS et al., 1999).

Several cervid species lack dispersal behavior as a means of population regulation. Thus, neither high density red deer (CLUTTON-BROCK et al., 1982), wapiti (SMITH and ROBBIns, 1994), nor mule deer (Odocoileus bemionus) (FLUECK, 1989) exhibited density-dependent dispersal.

Northern cervids exhibit seasonal reproduction and behavioral and physiological adaptations resulting in lipid deposition in autumn and lipid mobilization in winter (FLUECK, 1994 b). However, in man-modified ecosystems female mule deer were found with autumn fat reserves decreasing progressively over a 4 year period when they reached levels normally encountered only in winter-starved deer (FLUECK and SMITH-FLUECK, 1996). During that last summer $41 \%$ of adult females died due to starvation and average age dropped from 8.3 to 4.5 . years. Historical accounts on habitat and deer density were in contrast to the actual situation which was a result of modern land use practices. Flueck and SMITHFLUECK (1996) hypothesized that changes in the nutrient dynamics and forage availability allowed the deer population to become limited by food resources even in the presence of several predator species. However, mass dieoffs occur more frequently when predators have been exterminated (MITCHELL and STAINES, 1976; MUNRO, 1989; The Red Deer Commission, 1989; GREEN, 1993).

Density-dependent effects only near $K$, system instability when near $K$, irruptive behavior, and lack of density-dependent dispersal all result in population regulation through food limitation. The corollaries of this type of population regulation are therefore expressed in phenomena like population crashes after irruptions, mass starvation dieoffs in summer and winter, osteoporosis in calves, which are all generally considered by many authors as "natural" regulation (MTTCHELl and STAINES, 1976; CluTTON-BROCK et al., 1982; The Red Deer Commission, 1989; MUNRO, 1989; GreEN, 1993; MCCullough, 1997; SINGER et al., 1998). However, these cause-effect relationships are indicative of absence of self-regulating mechanisms among northern cervids and is good evidence that pristine populations were exposed to effective predation, which kept numbers below levels where intraspecific competition would lead to a selection for behavior, like territoriality, to regulate densities.

Irruptions: Wolves and puma were exterminated in most of the USA (MCCULLOUGH, 1997) followed by deer irruptions (BERGERUD et al., 1983 a; Gasaway et al., 1992; MCCULLOUGH, 1997) (Fig. $1 \mathrm{c}$ ). A combination of habitat change and loss of predators also resulted in irruptions (MARTin and KREFTing, 1953; Ellenberg, 1986; MAGNuSSON, 1993; LINDZEY et al., 1994) (Fig. 1 d). Irruptions lead to peak numbers unsupportable by vegetation and result in population crashes. Repeated occurrences of population growth to maximum carrying capacity are accompanied by nutritional stress and declining herd health (DAVIDSON and DOSTER, 1997). Many red deer died from undernutrition and heavy parasitism due to very high density as a result of extermination of all large predators (KLINGLER, 1966). Cervids introduced to islands without predators reach food-limited densities (HOWARD, 1964; FreELAND, 1990). Reindeer (Rangifer tarandus) brought to St. Matthew Island grew from 29 deer to some 6000 within 19 years (JEFFERIES et al., 1994). During one winter they crashed down to 50, and since no males survived, they went extinct.

Initial irruptions were suggested to lower $K$ for subsequent population responses (LEOPOLD, 1943), and to be more extreme than those produced by removal of competitors 
(CAUGHLEY, 1970). MCCULlOUGH (1997) refutes these views based on analysis of 3 cases of repeated irruptions because he could not detect diminution of subsequent population peaks. This however, was likely the result of not having any data on or manipulating the initial irruptions. MCCULLOUGH also concluded that the root cause of irruptions in northern herbivores are relationships between climate, vegetation, and herbivores; and as various mixtures of "natural" (e.g. starvation) and anthropogenic (e.g. cessation of hunting) factors cause irruptions and crashes, there is supposedly no single cause for irruptive behavior (MCCULLOUGH, 1997). This view confuses cause-effect relationships resulting in irruptions. It is the lack of self-regulation among large herbivores which results in irruptions.

As there are many ways to regulate herbivore populations nowadays, there are consequently many different situations resulting in irruptions. This includes removal of large predators from pristine settings; habitat change through logging or increased nutrient input (ELLENBERG, 1986; ELLENBERG, 1988); introductions, etc. which can all lead to irruptions if there is no hunting. Undoubtedly, the most notable and consistent factors leading to overabundance of cervids are man-caused changes in vegetation structure, in communities of large predator, and in nutrient cycles (MARTIN and KREFTING, 1953; LAUDENSLAYER and DARR, 1990; FLUECK, 1990, 1994 a; MAGNUSSON, 1993; FLUECK and SMITH-FLUECK, 1996; CLEMENTS and YOUNG, 1997). There are no reports of repeated deer irruptions in unmodified continental environments containing complete large predator and prey communities.

Effect on vegetation: In most natural systems, herbivores consume $10 \%$ or less of plant productivity, however, it is not day-to-day consumption that alters plant communities, but irruption of herbivores (MCSHEA and RAPPOLE, 1997). Cervids at high density in temperate forests have detrimental effect on conifer regeneration (AUGUSTINE and MCNAUGHTON, 1998) and can force systems into another stable vegetation complex, but different from pristine situations (STROMAYER and WARREN, 1997). For instance, at densities of 50/km², sika deer increased unpalatable species and some palatable ones went extinct (KAJI and YAJIMA, 1992). Forest stands follow the expected sequence of development and regenerate with deer density kept at $3-6 / \mathrm{km}^{2}$; in unhunted areas with density above $10 / \mathrm{km}^{2}$, oak forest could not be maintained (HEALY, 1997). Historically, available forage and predation in northeastern USA resulted in densities of about 4 deer $/ \mathrm{km}^{2}$ (DECALESTA, 1997). These forests were largely clearcut and large predators exterminated. Consequently, species richness, abundance and height of saplings of seçond growth forests declined significantly when deer density exceeded $8 / \mathrm{km}^{2}$; also formation of pre-settlement forests is now prevented, and several plant species have been eliminated (DECALESTA, 1997). The range of aspen (Populus tremuloides) has declined by $60-90 \%$ since European settlement in N. America and may be related to high densities of ungulates (KAY, 1997 b). However, if cervids and vegetation supposedly have co-evolved and occupy ecologically complete habitats, cervids should not cause retrogression of plant succession or range damage and associated changes in faunal elements (CHADDE, 1991; KAY, 1995 b; KAY and WALKER, 1997). In general, large herbivores at low density are not able to prevent closing of gaps in forest. However, high density results in impact on forest plant composition with extinction of preferred species (reviewed in VAN WIEREN, 1989). Analyzing deer density with respect to ecosystem qualities shows that to obtain optimal biodiversity, density was at less than $20 \%$ of $K$; for natural forest rejuvenation to continue it was $20-40 \%$ of $K$; highest deer yield was achieved at $40-60 \%$ of $K$; above $60 \%$ of $K$ body condition of animals was severely affected, vegetation suffered; and at $K$ there was zero recruitment (DECALESTA and STOUT, 1997). Moose are considered a keystone herbivore that likely mediate rates of nutrient cycling in northern ecosystems through positive feedback loops at low population density; however, at high density as through lack of predation, they initiate negative feedback loops (MOLVAR et al., 1993). 
Adaptions to predation: Female moose with calves typically choose areas with less quality food in order to avoid wolves (EDWARDS, 1983). Similar antipredator behavior has been shown for huemul and mountain sheep (FRID, 1994; BLEICH et al., 1997; FRID, 1999). On the other hand, cervids even in very good body condition due to low density were not able to escape predation (GASAWAY et al., 1992; SMITH-FLUECK and FLUECK, 1996; DIAZ and SMITH-FLUECK, 2000). As predator pressure increases, antipredator behavior intensifies resulting in decreased prey death rate (ABRAMS, 1993). Gregariousness is another antipredator behavior rather than to enhance food yield (HOBBS and SwIFT, 1988; BOWYER et al., 1997). These and other adaptions illustrate how predation greatly modifies plant-herbivore interactions and is an important source of natural selection processes.

\subsection{Ecological traits of pristine habitat}

Pre-agricultural temperate zones consisted principally of large tracks of mature forests. Before intense habitat modification by man, temperate forests were characterized by large areas of mature timber and only small openings of $1-2 \%$ created by natural disturbances (ZOLLER, 1993; DeCALESTA, 1997; HeALY, 1997). Cervid densities were very low in the USA in pristine times, based on first travelers reports, early photographs and modern decline in berry production (KAY, 1998). Historically, temperate forests rarely experienced large scale fires (NORRIS, 2000), whereas wind and disease were major agents of disturbance, with loss of individual trees or small groups of trees being the most common pattern of disturbance (RUNKLE, 1990; HANLEY, 1998; JAX, 1999). Eurasia had extensive old growth forests based on pollen studies (ZOLLER and HAAS, 1995) and all evidence indicates that under pristine conditions of dominating forests, large herbivores are not able to prevent closing of gaps in temperate forests; they are mere followers of succession (VAN WIEREN, 1989). When disturbance in a forest is of a larger scale, cervids can quickly respond numerically and reach densities temporarily and locally to the point where they are food limited (SCHWARTZ and FRANZMANN, 1991; MCLAREN and PETERSON, 1994). For instance, cervid density dropped $70 \%$ after a forest fire in Alaska. At the optimal stage of plant succession, cervids had again increased 10 -fold, but dropped $60 \%$ as the succession continued. Large predators at the same time had $13 \%$ intraspecific predation and $6 \%$ starvation at low cervid density which ceased completely at higher cervid density to which predators responded numerically (SCHWARTZ and FRANZMANN, 1991).

A major obstacle to study trophic relationships between temperate plant communities, large herbivores and their predators is lack of adequate study areas. For instance, outside Alaska, most wilderness areas in USA are deficient in large carnivores; most have none at all save black bear, and to a lesser extent, puma. All Long Term Ecological Research sites and virtually all biosphere reserves lack large top carnivores (PETERSON, 1988). Large predators were exterminated between 1700-1800 over large areas of North America and Europe, as were the original forests (BUETTNER, 1988; HEALY, 1997; DECALESTA, 1997). Remnant tracks of pristine forests in Europe are typified by low density of large herbivores, presence of large predators, and high biodiversity (TomialojC, 1991). In such areas, wolves and bear were responsible for $81 \%$ of adult moose mortality (YEVTIKOV, 1991). An unhunted Alaskan area with multiple herbivores and large predators showed $43 \%$ of caribou calves were killed by predators, considered to be a low estimate (ADAMs et al., 1995). Similarly, large predators were found to keep moose at low density as they killed $31 \%$ of the population annually; predation rate on calves and adults reached $70 \%$ and $90 \%$, respectively, and this mortality was shown to be additive (GASAwAY et al., 1992; KUNKEL and PLETSCHER, 1999). South American temperate forests still exhibit large tracks of old growth forests with small scaled gaps and low densities of native large herbivores, ranging between less 
than 1 to $5 / \mathrm{km}^{2}$ (SMITH-FLUECK and FLUECK, 1997; DiAZ and SMITH-FLUECK, 2000). Remains found of both sexes of huemul of all ages showed that $60 \%$ died due to predation (SMITH-FLUECK and FLUECK, 1996).

\section{Conclusion}

The divergent views on bottom-up versus top-down regulation of temperate large herbivores result in part from selecting component responses that can be determined in isolation, but which do likely not include those most relevant when the unit is imbedded in the complete system (UlANOWICZ, 1999). An additional fallacy is to draw conclusions for whole ecosystem behavior based on single prey - single predator studies when in reality there are multiple prey and multiple predator species. Moreover, logistic constraints and inappropriate methodology are main causes for erroneous conclusions. Lastly, many studies focus only on interactions between vegetation and herbivores without considering any modifying effect by predators (BARTMANN et al., 1992; KRÜSI et al., 1995; HOBBS, 1996; SINGER et al., 1998; GRENFELL et al., 1998).

Large predators play an important role in structuring communities. According to EISENBERG (1989), removal of top carnivores from ecosystems can have an impact on relative abundance of herbivore species within a guild. In the absence of predation, usually one or two species come to dominate the community resulting in direct alteration of the vegetation. Studies in pristine northern areas containing a complete assembly of large predators and herbivores clearly demonstrate the significant impact predators have on population dynamics of cervids which can be taken as prima facie evidence against the existence of self-regulation by cervids under pristine conditions. Therefore, modern man-caused changes to ecosystems, either by manipulating vegetation structure and composition, the predator community, or nutrient cycles must be significantly different from disturbance regimes which caused the genotypic and phenotypic patterns among northern large herbivores and predators.

To understand the reasons for existing discrepancies in interpreting population regulation of northern cervids, it is necessary to focus on data obtained from large herbivores in temperate systems due to basic differences in tropical systems or in relation with other types of prey species. Furthermore, as conclusive studies of such complex multi-species assemblages in pristine settings have not been done and likely will not be performed in the near future, it is warranted to rely on insight from other scientific fields to shed light on this issue. Foremost is the realization that the biosphere is a steady state system and therefore is governed by non-equilibrium thermodynamics. Furthermore, observed patterns in paleontological records and detailed analysis of nutrient cycles and food webs underlines the generality of irreversible increase in complexity as systems mature. The existence of intricately interacting multi-species assemblies of large northern herbivores and predators including social hunting types are an expression of these principles. The lack of top predators thus is not only an impoverishment - of biodiversity, but represents a loss of system functioning. The behavior of large herbivore when introduced or when the pristine community is altered, drastically attests that this group of animals lacks intrinsic mechanisms of self regulation; these organisms continue to reproduce as available per capita food intake decreases until death occurs due to exhaustion. It seems to be a scientific realism that population regulation of cervids is through predation although our ability to know and measure it may be limited. Considering the evolutionary history of temperate herbivores, it is a counterproductive enterprise to let man-modified systems regulate populations of large herbivores. It is just another human experiment with predictable outcome since food depri- 
vation leads to well known results. I concur with philosopher J. B. CALLICOTT who said: „... to hunt and kill deer in certain districts may not only be ethically permissible, it might actually be a moral requirement, necessary to protect the environment, taken as a whole, from the disintegrating effects of a cervid population explosion. "CALLICOTT, 1980). It is unethical to let large northern herbivore populations be regulated by food shortage.

Management Implications: Conclusions presented in this paper have several practical implications. Preeminent is the fact that northern cervids do not possess an intrinsic mechanism of self-regulation. Northern communities have evolved to and are functioning with a complex community of predators which regulated large herbivores under pristine conditions. Therefore, relationships between large herbivores and vegetation were predominantly modulated by the predator community and based on pristine nutrient cycles.

These relationships have been fundamentally altered by man through bringing about changes in the vegetation structure, the predator community, and the nutrient cycles. Under these modern conditions, large herbivore populations can respond numerically until becoming food limited, even with predators present. There a two important conclusions to be drawn:

1. Herbivore population densities above a critical level will inevitably cause shifts in community functioning by altering plant and animal species composition, and nutrient and energy flow patterns: the system will effectively be forced to a less complex and hence, less productive level, an evolutionary step backwards.

2. By having modified ecological parameters necessary for the welfare of herbivores, we need to take on the responsibility to guarantee their future welfare by actively replacing missing factors. For northern large herbivores it means implementing harvesting such that the population density permits natural plant rejuvenation and optimal biodiversity. Considering the welfare of large herbivores in man-modified situations and the benefits of higher system productivity and resilience, it is essential to restrain population growth of herbivore populations. The only practical means available is through harvesting programs based on hunting. These should be promoted at all levels and implemented on a regular basis. Where the predator community is still intact, it should be protected by all means, and where still possible, the predator community should be restored. A basic tool is to disseminate the best available information, namely that northern cervids do not exhibit self regulation. "Natural" regulation as is occurring in many situations is another expression for forced starvation.

\section{Acknowledgements}

I wish to thank J. SMITH-FLUECK, R. PRIBISH and two anonymous reviewers for valuable comments on the manuscript as well as $H$. SCHNEIDER and R. ULANOWICZ for greatly contriburing to the section on energy flow and cycling.

\section{Summary}

Understanding population regulation of large northern herbivores like cervids has important practical and theoretical implications. Corrective measures for high densities of cervids must be based on theory and thus necessitate analysis of contradicting views of top-down and bottom-up population control. The former considers cervids incapable of self-regulation and hence that they need external factors like predation to achieve effective population regulation. The latter claims that cervids exhibit the capacity to adjust their numbers to the food supply as shown by physiological responses. How- 
ever, these phenomena are not an expression of evolutionary adaption, they are a predictable physiological reaction to reduced food. In addition, studies were often done in man-modified environments or without considerations of modulating effects through predators. It is unlikely to study pristine relationships between large herbivores and predators in the future through field work, and insights from other fields need to be heeded. Considerations from evolution, thermodynamics, food webs and nutrient cycling indicate that the development of biological systems is unidirectional due to irreversible processes and leads toward optimal order and optimal accumulation of energy and nutrients. Large predators are thus not just a luxury development of evolution, but a necessary sequel to natural laws and they increase efficiency of the system to capture solar energy. It explains why analogous ecomorphs, like saber-tooth "cats" (placental and marsupial) have re-evolved independently at least 5 times. As a group, large predators developed traits allowing self-regulation including territoriality, intra- and interspecific killing, prey-switching, and dispersal. However, in man-modified environments, herbivore densities can reach such high levels that even an intact predator community will no longer exert regulation as there is an upper limit of predator density determined by social mechanisms. As kill success rates are very low, predators also affect herbivores by largely determining spacial distribution and behavioral adaptions, all of which modify herbivore-plant interactions. Cervids on the other hand exhibit traits all indicative of absence of a capacity to self-regulate. Predictable physiological responses to reduced food intake thus operate so late that the typical population response is an irruption with subsequent major dieoff and leads to a reduction in system performance including loss of biodiversity. Therefore, the claim that there exists "natural" regulation in such situations is an erroneous term for what is better called forced starvation. Two conclusions can be drawn:

1. Herbivore densities above a critical level will inevitably cause shifts in community functioning by altering plant and animal species composition, nutrient and energy flow patterns: the system will effectively be forced to a less complex and hence, less productive level, an evolutionary step backwards.

2. By having modified ecological parameters necessary for the welfare of herbivores, we need to take on the responsibility to guarantee their future welfare by actively replacing missing factors. For cervids it may mean implementing harvesting such that population densities permit natural plant rejuvenation and optimal biodiversity. Where the predator community is still intact, it should be protected by all means, and where still possible, predator communities should be restored. A basic tool is to disseminate the best available information, namely that large northern herbivores do not exhibit self regulation.

\section{Zusammenfassung}

\section{Bestandesregulierung von nördlichen Großherbivoren: Evolution, Thermodynamik und Großraubtiere}

Das Verständnis über Bestandesregulierung von nördlichen Groflherbivoren wie Cerviden hat wichtige praktische und theoretische Bedeutung. Lösungen für hohe Dichten von Cerviden müssen auf einer Theorie basieren und verlangen deshalb eine Analyse der sich widersprechenden Ansichten von top-down und bottom-up Regulierung. Die Erstere erkennt, dass Selbst-Regulierung unter Cerviden nicht besteht und dass Prädation für Bestandesregulierung notwendig ist. Die Letztere räumt den Cerviden ein, dass sie die Kapazität besitzen, ihren Bestand der Nahrungsquelle anzupassen. Dabei wird übersehen, dass dies keiner evolutionären Strategie, sondern vorhersagbaren physiologischen Reaktionen auf Nahrungsmangel entspricht. Zudem sind Studien oft in anthropogen modifizierter Umwelt oder ohne Berücksichtigung der modulierenden Effekte der Prädatoren gemacht worden. Durch die gegebene Schwierigkeit, zukünftig die ursprüngliche Beziehung zwischen nördlichen Großherbivoren und -raubtieren durch Feldstudien zu klären, ist es angebracht, sich auf andere relevante Wissensgebiete zu beziehen. Evolution, Thermodynamik, Analysen von Nahrungsketten und -zyklen deuten alle darauf hin, dass organische Entwicklung durch irreversible Prozesse richtungsspezifisch ist, sodass Ökosysteme optimale Ordnung und Anhäufung von Energie und Nährstoffen erreichen. Großraubtiere sind nicht nur luxuriöse Erscheinungen der Evolution, sondetn sind Folge der genannten Gesetze und erhöhen somit die Wirksamkeit des Systems im Abfangen solarer Energie. So wird verständlich, dass Evolution in analoger Weise Raubriertypen mehrere Male und innerhalb verschiedener Taxa hervorbrachte (z. B. 4 mal als Säbel-Säuger, aber auch als Säbel-Beuteltier). Zudem sind 
unter den Großraubtieren mehrere, für Selbst-Regulierung wichtige Charakteristika weitverbreitet: Territorialität, intra- und interspezifisches Töten, Prey-Switching und Dispersion. Im modifizierten Ökosystem können Dichten der Cerviden jedoch so hoch werden, dass auch eine intakte Räubergemeinschaft keine Regulierung mehr erreicht, weil die obere Grenze der Prädatorendichte durch Sozialverhalten bestimmt wird. Da die Wirksamkeit beim Beutefang sehr gering ist, beeinflussen Raubtiere zudem die Verbreitung und Verhaltensweise der Herbivoren, welche die Herbivore-Pflanzen Beziehung beeinflussen. Cerviden reagieren physiologisch auf Nahrungsmangel, prinzipiell unter extremen Bedingungen und so spät, dass die Pflanzengesellschaft schon schwer beschädigt ist und der Bestand ein Massensterben erleidet. Die Behauptung, dass in solchen Situationen "natürliches Selbst-Regulieren" existiert, ist ein irrtümliches Konzept, das besser als forciertes Verhungern bezeichnet werden sollte. Die Integration der Herbivoren im Ökosystem entstand unter ständiger Bestandeskontrolle durch die Großraubtiergemeinschaft, d. h. die Beziehung zwischen Pflanzengemeinschaft und Herbivoren wurde prinzipiell durch Raubtiere moduliert. Nur in der Kulturlandschaft finden sich Bestände von Herbivoren, die ausschlieflich durch das Nahrungsangebot reguliert werden. Daraus lassen sich zwei Schlüsse ziehen:

1. Die Dichte von Herbivoren über ein Limit hinaus führt unweigerlich zu Verschiebungen in der Pflanzen- und Tierartenzusammensetzung, und des Musters der Stoff- und Energieflüsse: das System wird effektiv auf einen weniger komplexen Stand und zu abnehmender Produktivität gebracht, ein evolutionärer Rückschritt.

2. Die anthropogene Modifizierung der für das Wohlergehen der Herbivoren nötigen ökologischen Parameter verlangt, dass wir mit entsprechender Verantwortung dieselben ersetzen, sodass das zukünftige Wohlergehen der Herbivoren garantiert wird. Für Cerviden bedeutet das die Durchführung der Jagd, sodass die Bestandesdichte optimale Biodiversität und natürliche Verjüngung erlaubt. Wo die Raubwildgemeinschaft immer noch intakt ist, sollte sie mit allen Mitteln geschützt werden, und wo immer noch möglich, soll die Gemeinschaft wieder instand gesetzt werden.

\section{Résumé}

\section{Régulation de population chez les grands herbivores de l'hêmisphère Nord : évolution, thermodynamique et grands prédateurs}

La compréhension de la régulation de populations des grands herbivores de l'hémisphère Nord tels que les Cervidés comporte des implications pratiques et théoriques importantes. Des mesures visant à corriger de fortes densités en Cervidés doivent être basées sur la théorie et nécessitent donc une analyse d'approches contradictoires du contrôle de population du sommet vers le bas et de la base vers le haut de la pyramide écologique. La première considère les Cervidés incapables d'auto-régulation, nécessitant dès lors, pour assurer une régulation de population effective, l'intervention de facteurs externes tel que la prédation. La seconde prétend que les Cervidés possèdent la capacité d'ajuster leur nombre aux ressources alimentaires par des réponses physiologiques. Cependant, on perd de vue que ces phénomènes ne sont pas une expression d'une stratégie évolutive, mais qu'lls correspondent plutôt à une réaction physiologique prévisible vis-à-vis d'une réduction des ressources alimentaires. En outre, les recherches ont souvent été réalisées dans des milieux altérés par l'homme ou sans tenir compte des effets modulateurs causés par les prédateurs. Compte tenu de cette difficulté d'expliquer dans le futur, par des études de terrain, la relation originelle entre les grands herbivores et les grands prédateurs de l'hémisphère Nord, il s'impose de s'en référer à d'autres sources pertinentes de connaissances. Evolution, thermodynamique, analyses des chaînes et des cycles alimentaires concluent toutes au fait que le développement de systèmes biologiques procède par des processus irréversibles et dans une direction bien déterminée, pour aboutir à une allocation optimale de l'énergie et des composants alimentaires. Les grands prédateurs ne sont donc pas comme une sorte de luxe de l'évolution mais une conséquence nécessaire des lois naturelles en question, augmentant de la sorte l'efficacité du système en ce qui concerne la mobilisation de l'énergie solaire. Ceci explique pourquoi l'évolution a, à différentes reprises et de façon analogue, développé des écomorphes au sein de différents taxons; ainsi les * chats * à dènts de sabre (placentaire et marsupial) ont-ils ré-évolués indépendamment au moins 5 fois. Comme grou$\mathrm{pe}$, les grands prédateurs ont développé des caractères autorisant l'auto-régulation, tels que la territorialité, la prédation intra- et interspécifique, l'alternance de proies et la dispersion. Cependant, dans les milieux modifiés par l'homme, les densités d'herbivores atteignent de telles proportions que même une zoocénose intacte de prédateurs ne serait plus en mesure d'exercer une régulation du fait que des 
mécanismes sociaux définissent une limite supérieure à la densité des prédateurs. Comme les taux de mortalité par prédation sont très faibles, les prédateurs agissent également sur la dispersion et le comportement des herbivores, lesquels influencent à leur tour les rapports herbivores - végétation. La réponse physiologique des Cervidés à un manque de nourriture n'intervient en principe que lorsque les conditions sont extrêmes et fort tardivement, c'est-à-dire lorsque le tapis végétal est déjà fortement endommagé et lorsque la population subit des mortalités massives. L'affirmation selon laquelle intervient, dans de telles situations, une * auto-régulation naturelle * est un concept erroné qui devrait plutôt être désigné sous le nom d'épuisement suite à une famine forcée. L'intégration des herbivores dans l'écosystème trouve son origine dans un contrôle permanent du niveau de population par la communauté des grands carnivores, c'est-à-dire que la relation entre la végétation et les herbivores est en principe modulé par les prédateurs. Ce n'est que dans le paysage cultivé que l'on trouve des herbivores qui sont exclusivement régulés par les ressources alimentaires. De tout ceci on peut tirer deux conclusions :

1. une densité dépassant un certain niveau conduit inexorablement à des glissements vers des compositions floristique et faunistique ainsi que vers des flux de l'énergie et de la matière : le système est effectivement ramené à un niveau moins complexe et à une productivité moindre, ce qui correspond à une régression évolutive;

2. la modification anthropogène des paramètres écologiques, nécessaires à l'épanouissement des herbivores, exige que nous procédions au remplacement des mêmes de façon responsable, de telle sorte que le bien-être futur des herbivores soit assuré. Pour les Cervidés, cela signifie la poursuite de la chasse de manière à ce que la densité de population permette une biodiversité optimale et une régénération naturelle. Là où la communauté des prédateurs est toujours intacte, il convient de la protéger par tous les moyens et, là où la chose est toujours possible, cette communauté de prédateurs doit à nouveau être restaurée.

Trad. : S. A. DE CROMbrugGHE

\section{References}

ABRAMS, P. A., 1993: Why predation rate should not be proportional to predator density. Ecology 74, 726-733.

ADAMS, L. G.; SINGER, F. J.; DALE, B. W., 1995: Caribou calf mortality in Denali National park, Alaska. J. Wildl. Manage. 59, 584-594.

AlBon, S. D.; COULSON, T. N.; CluTtON-BROCK, T. H., 1998: Demographic constraints in red deer (Cervus elapbus): can the past predict the future? In: MILNE, J. A. (ed.), Recent developments in deer biology Edinburgh, UK: Moredun Res. Inst., pp. 85-95.

ANDERSON, A. E.; BOWDEN, D. C.; KATTNER, D. M., 1992: The puma on Uncompahgre Plateau, Colorado. Techn. Publ. No. 40. Ft. Collins, Colorado, USA: Colorado Division of Wildlife. 116 pp.

Augustine, D. J; MCNAUGHTON, S. J., 1998: Ungulate effects on the functional species composition of plant communities: herbivore selectivity and plant tolerance. J. Wildl. Manage. 62, 1165-1183.

BAILEY, T. N., 1974: Social organization in a bobcat population. J. Wildl. Manage. 38, 435-446.

BAINES, D.; SAGE, R. B.; BAINES, M. M., 1994: The implications of red deer grazing to ground vegetation and invertebrate communities of Scottish native pinewoods. J. Appl. Ecol. 31, 776-783.

BALLARD, W. B., 1992: Modelled impacts of wolf and bear predation on moose calf survival. Alces 28 : 79-88.

BaLlaRd, W. B.; AYRES, I. A.; KRAUSMAN, P. R.; REED, D. J. et al., 1997: Ecology of wolves in relation to a migratory caribou herd in Northwest Alaska. Wildl. Monogr. 135, 47.

BALLARD, W. B.; MILLER, S. D., 1992: Effects of reducing brown bear density on moose calf survival in southcentral Alaska. In: BOBEK, B.; PERZANOWSKI, K.; REGELIN, W. L. (eds.), Global trends in wildlife management. Krakow, Poland: Swiat Press, Vol. 2, pp. 171-175.

BAILARD, W. B; MLLLER, S. D.; WHITMAN, J. S., 1992; Brown and black bear predation on moose in southcentral Alaska. In: BOBEK, B.; PERZANOwskI, K.; REgeLiN, W. L. (eds.), Global trends in wildlife management. Krakow, Poland: Swiat Press, Vol. 2, pp. 177-184.

Ballard, W. B.; Whitlaw, H. A.; Young, S. J.; Jenkins, R. A. et al., 1999: Predation and survival of white-tailed deer fawns in Northcentral New Brunswick. J. Wildl. Manage. 63, 574-579.

Ballard, W. B.; Whttman, J. S.; REED, D. J., 1991: Population dynamics of moose in south-central Alaska. Wildl. Monogr. 114, 49. 
BARMORE, W. J.; STRADleY, D., 1971: Predation by black bear on mature male elk. J. Mammal. 52.

BARTMANN, R. M.; WhITE, G. C.; CARPENTER, L. H., 1992: Compensatory morality in a Colorado mule deer population. Wildl. Monogr. 121: 39.

Beltran, J. F.; AlDAMA, J. I.; Delibes, M., 1992: Ecology of the Iberian lynx in Donana, SW Spain. In: BOBEK, B.; PERZANOwSKI, K.; REGELIN, W. L. (eds.), Global trends in wildlife management. Krakow, Poland: Swiat Press, Vol. 2, pp. 331-334.

BERGERUD, A. T., 1971: The population dynamics of Newfoundland caribou. Wildl. Monogr. 25, 1-55.

Bergerud, A. T.; NOLAN, M. J.; CURNew, K.; MERCER, W. E., 1983 a: Growth of the Avalon Penninsula, Newfoundland caribou herd. J. Wildl. Manage. 47, 989-998.

Bergerud, A. T.; SNIDER, J. B., 1988: Predation in the dynamics of moose populations: a reply. J. Wildl. Manage. 52, 559-564.

BERGERUD, A. T.; WYETT, W.; SNIDER, B., 1983 b: The role of wolf predation in limiting a moose population. J. Wildl. Manage. 47, 977-988.

BiBIKOw, D. I., 1988: Der Wolf. Wittenberg, Lutherstadt: Neue Brehm-Bücherei. 587 pp.

BJARVALL, A.; DANIELSSON, S.; FRANZEN, R.; SEgersTrom, P., 1996: Experiences with the first radiocollared wolverines in Sweden. J. Wildl. Res. 1, 3-6.

BLEICH, V. C.; BOWYER, R. T.; WEHAUSEN, J.D., 1997: Sexual segregation in mountain sheep: resources or predation? Wildl. Monogr. 134, 1-50.

BOBEK, B.; PERZANOWSKI, K.; SMIETANA, W., 1992: The influence of snow cover on wolf (Canis lupus) and red deer (Cervus elaphus) relationship in Bieszczady mountains. In: BOBEK, B.; PERZANOws$\mathrm{KI}, \mathrm{K} . ;$ REGELIN, W. L. (eds.), Global trends in wildlife management. Krakow, Poland: Swiat Press, Vol. 2, pp. 341-348.

BoutiN, S., 1992: Predation and moose population dynamics: a critic. J. Wildl. Manage. 56, 116-127.

BOWYER, R. T.; BALLENBERGHE, V. V.; KIE, 1997: The role of moose in landscape processes: effects of biogeography, population dynamies, and predation. In: Bissonette, J. A. (ed.), Wildlife and Landscape Ecology, Effects and Patterns of Scale. New York: Springer, pp. 265-287.

Boyd, D. K.; ReAm, R. R.; Pletscher, D. H.; FaIRCHILD, M. W., 1994: Prey taken by colonizing wolves and hunters in the Glacier National park area. J. Wildl. Manage. 58, 289-295.

Breitenmoser, U.; Haller, H., 1993: Patterns of predation by reintroduced European lynx in the Swiss alps. J. Wildl. Manage. 57, 135-144.

BRODIE, E. D.; BRODIE, E. D., 1999: Predator - prey arms races. BioScience 49, 557-568.

BÜTTNER, K., 1988: Die Wiedereinbürgerung von Raubwild aus waldhygienischer Sicht. Waldhygiene $17,129-146$.

BUfKA, L.; CERVENY, J., 1996: The lynx (Lynx lynx) in the Sumava region, southwest Bohemia. J. Wildl. Res. 1: 167-170.

CALLICOTT, J. B., 1980: Animal liberation: a triangular affair. Environmental Ethics 2, 311-325.

CArbYN, L. N., 1983: Wolf predarion on elk in Riding Mountain National Park, Manitoba. J. Wild!. Manage. 47, 963-976.

CAUGHLEY, G., 1970: Eruption of Ungulate Populations, with Emphasis on himalayan Thar in New Zealand. Ecology 51, 53-72.

CHADDE, S. W. K. C. E., 1991: Tall-willow communities on Yellowstone's northern range: a test of the "Natural-Regulation" paradigm. In: KeITER, R. B.; BOYCE, M. S. (eds.), The Greater Yellowstone Ecosystem: Redefining America's Wilderness Heritage. Yale Univ. Press, USA: pp. 231-262.

Chamberlain, M. J.; Leopold, B. D.; Burger, L. W.; Plowman, B. W. et al., 1999: Survival and cause-specific mortality of adult bobcats in central Mississippi. J. Wildl. Manage. 63, 613-620.

CLEMENTS, C. C.; YouNG, J. A., 1997: A viewpoint: rangeland health and mule deer habitat. J. Range Manage. 50, 129-138.

ClutToN-Brock, T. H.; Guinness, F. E.; Albon, S. D., 1982: Red Deer: Behavior and Ecology of two Sexes. Chicago: The University of Chicago Press. 378 pp.

DANILOV, P. I., 1990: The brown bear in Soviet Karelia. Trans. Int. Union Game Biologists 19, 566-572.

DAvidSON, W. R.; DOSTER, G. L., 1997: Health characteristics and white-tailed deer population density in the Southeastern Unites States. In: MCSHEA, W. J.; UNDERWOOD, H. B.; RAPPOLE, J. H. (eds.), The science of overabundance: deer ecology and population management. Washington, USA: Smithsonian Inst. Press, pp. 164-184.

DeANGelis, D. L., 1992: Dynamics of nutrient cycling and food webs. London, England: Chapman \& Hall. $270 \mathrm{pp}$.

DECALESTA, D. S., 1994: Effect of white-tailed deer on songbirds within managed forests in Pennsylvania. J. Wildl. Manage. 58, 711-718. 
DeCAlESTA, D. S., 1997: Deer and ecosystem management. In: MCSHEA, W. J; UNDERWOOD, H. B.; RAPPOLE, J. H. (eds.), The science of overabundance: deer ecology and population management. Washington, USA: Smithsonian Inst. Press, pp. 267-279.

DeCALESTA, D. S.; STOUT, S. L., 1997: Relative deer density and sustainability: a conceptual framework for integrating deer management with ecosystem management. Wildl. Soc. Bull. 25, 252-258.

DIAZ, N.; SMITH-FLUECK, J., 2000: The Patagonian huemul. A mysterious deer on the brink of extinction. Buenos Aires: Literature of Latin America. 149 pp.

EDWARDS, J., 1983: Diet shifts in moose due to predator avoidance. Oecologia 60, 185-189.

EISENBERG, J. F., 1989: An introduction to the carnivora. In: GITTLEMAN, J. L. (ed.), Carnivore behavior, ecology, and evolution. Ithaca, New York: Comstock Publ. Associates, pp. 1-9.

EllenBerG, H., 1986: Immissionen - Produktivität der Krautschicht - Populationsdynamik des Rehwilds: Ein Versuch zum Verständnis ökologischer Zusammenhänge. Z. Jagdwiss. 32, 171-183.

ELLENBERG, H., 1988: Eutrophierung - Veränderungen der Waldvegetation - Folgen für den RehWildverbiss und dessen Rückwirkungen auf die Vegetation. Schweiz. Z. Forstwes. 139, 261-282.

ERLINGE, S.; GoERANSSON, G.; HOEGSTEDT, G.; JANSSON, G. et al., 1984: Can vertebrate predators regulate their prey? Am. Naturalist 123, 125-133.

ESTES, J. A., 1996: Predators and ecosystem management. Wildl. Soc. Bull. 24, 390-396.

FILONOV, C., 1980: Predator-prey problems in nature reserves of the European part of the RSFSR. J. Wildl. Manage. 44, 389-396.

FLUECK, W. T., 1989: The effect of selenium on reproduction of black-tailed deer (Odocoileus bemionus columbianus) in Shasta County, California. Dissertation, University of California, Davis, California: pp. 284.

FLUECK, W. T., 1990: Possible impact of immissions on trace mineral availability to free-ranging ruminants: selenium as an example. Z. Jagdwiss. 36, 179-185.

FLUECK, W. T.; SMITH-FLUECK, J. M., 1990: Selenium deficiency in deer: the effect of a declining selenium cycle? Trans. Congr. Int. Union Game Biol. 19, 292-301.

FLUECK, W. T., 1994 a: Effect of trace elements on population dynamics: selenium deficiency in freeranging black-tailed deer. Ecology 75, 807-812.

FLUECK, W. T., 1994 b: Relationship between body weight, lipid reserves, and ovulation rate in nonequatorial cervids: a hypothesis. Z. Jagdwiss. 40, 12-21.

FLUECK, W. T.; SMITH-FLUECK, J. M., 1996: Can energy deficiency cause deer die-offs on northern mountain ranges? an exploratory analysis of Odocoileus bemionus. Z. Jagdwiss. 42, 85-96.

FOWLER, C. W., 1981: Density dependence as related to life history strategy. Ecology 62, 602-610.

FREELAND, W. J., 1990: Large herbivorous mammals: exotic species in northern Australia. J. Biogeogx. $17,445-449$.

FRID, A., 1994: Observations on habitat use and social organization of a huemul (Hippocamelus bisulcus) coastal population in Chile. Biol. Conserv. 67, 13-19.

FRID, A., 1997: Vigilance by female Dall's sheep: interactions between predation risk factors. Anim. Behav. 53, 799-808.

Frid, A., 1999 in press: Huemul (Hippocamelus bisulcus) sociality at a periglacial site: sexual aggregation and habitar effects on group size. Can. J. Zool.

FrYXELL, J. M., 1991: Forage quality and aggregation by large herbivores. Amer. Naturalist 138, 478-498.

FULLER, T. K., 1989: Population dynamics of wolves in north-central Minnesota. Wildl. Monogr. 105, 41.

Gaillard, J. M.; Festa-Bianchet, M.; Yoccoz, N. G., 1998: Population dynamics of large herbivores: variable recruitment with constant adult survival. Trends Ecol. Evol. 13, 58-63.

GasawaY, W. C.; BoerTJe, R. D.; GrangaARD, D. V.; KelleyHouSE, D. G. et al., 1992: The role of predation in limiting moose at low densities in Alaska and Yukon and implications for conservation. Wildl. Monogr. 120, 59.

GORDON, I. J.; LINDSAY, W. K., 1990: Could mammalian herbivores "manage” their resources? Oikos 59, 270-280.

Gorman, M. L.; TROWBRIDGE, B. J., 1989: The role of odor in the social lives of carnivores. In: GrTTLEMAN, J. L. (ed.), Carnivore behavior, ecology, and evolution: Ithaca, New York: Comstock Publ. Associates, pp. 57-88.

Gould, S. J., 1989: Wonderful life. New York: W. W. Norton $8 x$ Comp., 347 pp.

GREEN, R., 1993: Deer mortality on a Scottish forest. Deer 9, 8. 
Grenfell, B. T; Wilson, K.; FinkenstadT, B. F; CoulsON, T. N. et al., 1998: Noise and determinism in synchronized sheep dynamics. Nature 394, 674-677.

HAIRSTON, N. G., 1964: Studies on the organization of animal communities. J. Anim. Ecol. 33, 227-239.

Hatrston, N. G.; SMITH, F. E.; SLOBodkIN, L. B., 1960: Community structure, population control, and competition. Am. Naturalist 94, 421-425.

HANLEY, T. A., 1998: Black-tailed deer (Odocoileus bemionus) and forest management in Alaska: practical lessons from the pursuit of foraging theory. In: MLNE, J. A. (ed.), Recent developments in deer biology. Edinburgh, UK.: Moredun Res. Inst., pp. 401-409.

HANSEN, L. P.; NIXON, C. M.; BERINGER, J., 1997: Role of refuges in the dynamics of outlying deer populations. In: MCSHEA, W. J.; UNDERWOOD, H. B.; RAPPOLE, J. H. (eds.), The science of overabundance: deer ecology and population management. Washington, USA: Smithsonian Inst. Press, pP. 327-345.

HARrison, D. J.; HARRISON, J. A., 1984: Foods of adult Maine coyotes and their known-aged pups. J. Wildl. Manage. 48, 922-926.

HEALY, W. M., 1997: Influence of deer on the structure and composition of oak forests in central Massachusetts. In: MCSHEA, W. J.; UNDERWOOD, H. B.; RAPPOLE, J. H. (eds.), The science of overabundance: deer ecology and population management. Washington, USA: Smithsonian Inst. Press, PP. 249-266.

HENKE, S. E.; BRYANT, F. C., 1999: Effects of coyote removal on the faunal community in western Texas. J. Wildl. Manage. 63, 1066-1081.

HовBS, N. T., 1996: Modification of ecosystems by ungulates. J. Wildl. Manage. 60, 695-713.

HoBBS, N. T.; SwIFT, D. M., 1988: Grazing in herds: When are nutritional benefits realized? Am. Naturalist 131, 760-764.

HORNOCKER, M. G., 1970: An analysis of mountain lion predation upon mule deer and elk in the Idaho primitive area. Wildl. Monogr. 21, 1-39.

HORNOCKER, M. G.; BAILEY, T., 1986: Natural regulation in three species of felids. In: MiLleR, S. D.; EVERETT, D. D. (eds.), Cats of the world: biology, conservation and management. Natl. Wildl. Fed., WASHINGTON, D. C., pp. 211-220.

HORNOCKER, M. G.; HASH, H. S., 1981: Ecology of the wolverine in northwestern Montana. Canadian J. Zool. 59, 1286-1301.

HoWARD, W. E., 1964: Modification of New Zealand's flora by introduced mammals. Proc. N. Z. Ecol. SOc.: 59-62.

HUgGard, D. J., 1993 a: Prey selectivity of wolves in Banff National park. I. Prey species. Can. J. Zool. $71,130-139$.

HugGard, D. J., 1993 b: Prey selectivity of wolves in Banff National park. II. Age, sex, and condition of elk. Can. ]. Zool. 71, 140-147.

HUNT, R. M., 1996: Biogeography of the order Carnivora. In: GrtTLEMAN, J. L. (ed.), Carnivore behavior, ecology, and evolution. Ithaca, New York: Comstock Publ. Associates, pp. 485-541.

JAx, K., 1999: Natürliche Störungen: ein wichtiges Konzept für Ökologie und Naturschutz? Z. Ökol. Naturschutz 7, 241-253.

JEFFERIES, R. L.; KLEIN, D. R.; SHAVER, G. R., 1994: Vertebrate herbivores and northern plant communities: reciprocal influences and responses. Oikos 71, 193-206.

JOBIN, A.; MOLINARI, P; BREITENMOSER, U., 1999: Prädationsmuster des Eurasischen Luchses im Schweizer Jura. 3rd European Congress of Mammalogy, Jyvaskyla, Finland.

KAJl, K.; YAJMA, T., 1992: Influence of Sika deer on forests of Nakanoshima Island, Hokkaido. In: BOBEK, B.; PERZANOWSKI, K.; REgelIN, W. L. (eds.), Global trends in wildlife management. Krakow, Poland: Swiat Press, Vol. 2, pp. 215-218.

KAY, C. E., 1995 a: Aboriginal overkill and native burning: implications for moden ecosystem management. West. J. Appl. For. 10, 121-126.

KAY, C. E., 1995 b: Browsing by native ungulates: effects on shrub and seed production in the Greater Yellowstone ecosystem. In: Roundy, B. A.; MCARTHUR, E. D.; HALEY, J. S.; MANN, D. K. (eds.), Proc. Wildland Shrub Arid Land Restor. Symp. Intermountain Res. Stn., Ogden, UT., pp. 310-320.

KAY, C. E., 1997 a: Aboriginal overkill and the biogeography of moose in western North America. Alces 33, 141-164.

KAY, C. E., 1997 b: Is aspen doomed? J. Forestry 95, 4-11.

KAY, C. E., 1998: Are ecosystems structured from the top-down or bottom-up: a new look at an old debate. Wildl. Soc. Bull. 26, 484-498. 
KAY, C. E.; WALKER, J. W., 1997: A comparison of sheep- and wildlife-grazed willow communities in the Greater Yellowstone ecosystem. Sheep \& Goat Res. J. 13, 6-14.

$\mathrm{KAY}, \mathrm{J}$., 2000 in press: Ecosystems as self-organizing holarchic open systems: narratives and the second law of thermodynamics. In: Handbook of Ecology.

KEITH, L. B., 1974: Some features of population dynamics of mammals. Proc. XI Intern. Congr. Game Biologists: 17-58.

KLINGLER, K., 1966: Sektionsbefunde von Rotwild aus dem schweizerischen Nationalpark und den umliegenden Gebieten. Ergebnisse d. wiss. Untersuchungen i. Schweizer Nationalpark 11, 1-11.

KOEHLER, G. M.; HORNOCKER, M. G., 1991: Seasonal resource use among mountain lions, bobcats, and coyotes. J. Mammal. 72, 391-396.

KRUSI, B. O.; SCHUTT, M.; WILDI, O.; GRAMIGER, H., 1995: Huftiere, Vegetationsdynamik und botanische Vielfalt im Nationalpark. Cratschla (Switzerland) 3, 14-25.

Kunkel, K. E.; RUTH, T. K.; PleTSCHER, D. H.; HORNOCKER, M. G., 1999: Winter prey selection by wolves and cougars in and near Glacier National park, Montana. J. Wildl. Manage. 63, 901-910.

Kunkel, K.; PletsCher, D. H., 1999: Species-specific population dynamics of cervids in a multipredator ecosystem. J. Wildl. Manage. 63, 1082-1093.

LARSEN, D. G.; GAUTHIER, D. A.; MARKEL, R. L., 1989: Causes and rate of moose mortality in the southwest Yukon. J. Wildl. Manage. 53, 548-557.

LAUDENSLAYER, W. F; DARR, H. H., 1990: Historical effects of logging on the forests of the Cascade and Sierra Nevada ranges of California. Trans. West. Sec. Wildl. Soc. 26, 12-23.

LEOPOLD, A., 1943: Deer irruptions. Wisconsin Conserv. Bull. 8, 3-11.

LEwIS, M. A.; MURRAY, J. D., 1993: Modeling territoriality and wolf deer interactions. Nature 366, 738-740.

LIMA, S. L., 1992: Life in a multi-predator environment: some considerations for anti-predatory vigilance. Ann. Zool. Fennici 29, 217-226.

LINDZEY, F. G.; ACKERMAN, B. B.; BARNHURST D.; HEMKER, T. P., 1988: Survival rates of mountain lions in southern Utah. J. Wild!. Manage. 52, 664-667.

Lindzey, F. G.; VAN SiCKLE, W. D.; ACKerman, B. B.; Barnhurst D. et al., 1994: Cougar population dynamics in southern Utah. J. Wildl. Manage. 58, 619-624.

LiNDZEY, F. G.; VAN SICKLE, W. D.; LAING S. P.; MEChAM, C. S., 1992: Cougar population response to manipulation in southern Utah. Wildl. Soc. Bull. 20, 224-227.

LOTKA, A. J., 1925: Elements of physical biology. Baltimore, USA: Williams and Wilkins.

MACE, R. D.; WALLER, J. S., 1997: Spatial and temporal interaction of male and female grizzly bears in northwestern Montana. J. Wild1. Manage. 61, 39-52.

MAGNUSSON, M., 1993: Red deer and Scotland's Natural Heritage. Deer 9, 19-22.

Marshal, J. P.; Boutin, S., 1999: Power analysis of wolf-moose functional responses. J. Wildl. Manage. $63,396-402$.

Martin, F. R.; KREFTING, L. W., 1953: The Necedah refuge deer irruption. J. Wildl. Manage. 17, 166-176.

MARTIN, L. D., 1989: Fossil history of the terrestrial carnivora. In: GITTLEMAN, J. L. (ed.), Carnivore behavior, ecology, and evolution. Ithaca, New York: Comstock Publ. Associates, pp. 536-568.

MCCullovgh, D. R., 1997: Irruptive behavior in ungulates. In: MCSHEA, W. J; UNDERWOOD, H. B.; RAPPOLE, J. H. (eds.), The science of overabundance: deer ecology and population management. Washington, USA: Smithsonian Inst. Press, pp. 69-98.

Mclaren, B. E.; Peterson, R. O., 1994: Wolves, moose, and tree rings on Isle Royal. Science 266, 1555-1558.

MCSHEA, W. J.; RAPPOLE, J. H., 1997: Herbivore and the ecology of forest understory birds. In: MCSHEA, W. J.; UNDERWOOD, H. B.; RAPPOLE, J. H. (eds.), The science of overabundance: deer ecology and population management. Washington, USA: Smithsonian Inst. Press, pp. 298-309.

MECH, L. D., 1987: Age, season, distance, direction, and social aspects of wolf dispersal from a Minnesota pack. In: CHEPKO-SADE, B. D.; TANG HALPIN, Z. (eds.), Mammalian dispersal patterns. Chicago, USA: The Univ. Chicago Press, pp. 55-74.

MECF, L. D.; KARNS, P. D., 1977: Role of the wolf in a deer decline in the superior National forest. USDA Forest Service, Research Paper NC-148, 23.

MESSIER, F., 1991: The significance of limiting and regulating factors on the demography of moose and white-tailed deer. J. Anim. Ecol. 60, 377-393.

MESSIER, F.; CRETE, M., 1984: Body condition and population regulation by food resources in moose. Oecologia $65,44-50$. 
MESSIER, F.; CRETE, M., 1985: Moose-wolf dynamics and the natural regulation of moose populations. Oecologia 65, 503-512.

Miller, S. D.; WHTTE, G. C.; SELleRs, R. A.; ReYNOLDS, H. V. et al, 1997: Brown and black bear density estimation in Alaska using radiotelemetry and replicated mark-resight techniques. Wildl. Monogr. 133, 55 .

MITCHELL, B.; STAINES, B. W., 1976: An example of natural winter mortality in Scottish red deer. Deer 3, 549-552.

MOLVAR, E. M.; BOWYrR, R. T.; Van Ballenberghe, V., 1993: Moose herbivory, browse quality, and nutrient cycling in an Alaskan treeline community. Oecologia 94, 472-479.

MOROwIT, H. J., 1968: Energy flow in biology. New York: Academic Press, Inc. 179 pp.

MUNRO, R., 1989: Deer mortality at Camusrory: a veterinary report. Deer 7, 528-529.

MUSZYNSKA, M., 1996: Comparison of the spring and summer diet of the wolf and the red fox in the Bieszczady mountains. J. Wildl. Res. 1, 182-185.

NORRIS, S., 2000: Reading berween the lines. BioScience 50, 389-394.

NOVARO, A. J.; FUNES, M. C. WALKER, R. S., 2000: Ecological extinction of native prey of a carnivore assemblage in Argentine Patagonia. Biol. Conserv. 92, 25-33.

ODUM, E. P., 1991: Prinzipien der Ökologie: Lebensräume, Stoffkreisläufe, Wachstumsgrenzen. Heidelberg, Germany: Spektrum-der-Wissenschaft-Verlagsgesells. 305 pp.

Odum, H. T.; Pinkerton, R. C., 1955: Times speed regulation, the optimum efficiency for maximum output in physical and biological systems. Amer. Sci. 43, 331-343.

OKARMA, H.; JEDRZEJEWISKI, W; SCHMIDT, K.; KOWALCZYK, R. et al, 1997: Predation of Eurasian lynx on roe deer and red deer in Bialowieza Primeval forest, Poland. Acta Theriol. 42, 203-224.

PAQUET, P. C., 1992: Prey use strategies of sympatric wolves and coyotes in Riding Mountain National Park, Manitoba. J. Mamm. 73, 337-343.

Parker, G. R.; MAXwell, L. W; MORTON, L. D.; SMITH, G. E., 1983: The ecology of the lynx (Lynx canadensis) on Cape Breton island. Can. J. Zool. 61, 770-786.

PECHACEK, P., 1994: Einfluss der Wölfe auf Schalenwild in der Slowakei. Allg. Forstzeitschrift 19, $1058-1060$.

PETERSON, R. O,, 1988: The pit or the pendulum: issues in large carnivore management in natural ecosystems. Ecosystem Management for Parks and Wilderness: 105-115.

PLeTSCHER, D. H.; REAM, R. R.; BOYD, D. K.; FAIRChild, M. W. et al., 1997: Population dynamics of a recolonizing wolf population. $J$. Wildl. Manage. $61,459-465$.

POLLACK, E. M., 1951: Food habits of the bobcat in the New England states. J. Wildl. Manage. 15, 209-213.

POOLE, K. G., 1994: Characteristics of an unharvested lynx population during a snowshoe hare decline. J. Wildl. Manage. 58, 608-618.

Putman, R. J.; EDwards, P. J.; MANN, J. C.; How, R. C. et al., 1989: Vegetational and faunal changes in an area of heavily grazed woodland following relief of grazing. Biol. Conserv. 47, 13-32.

PYRAH, D., 1984: Social distribution and population estimates of coyotes in North-Central Montana. J. Wildl. Manage. 48, 679-690.

Reig, S.; Cuesta, L.; Palacios, F; Barcena, F., 1992: Status of the wolf in Spain. In: Bobek, B.; PerZANOwsKI, K.; REgeLIN, W. L. (eds.), Global trends in wildlife management. Krakow, Poland: Swiat Press, Vol. 2, pp. 371-374.

RINEY, T, 1964: The impact of introductions of large herbivores on the tropical environment. IUCN Publ. New Series: 261-273.

RUNKLE, J. R., 1990: Gap dynamics in an Ohio Acer-Fagus forest and speculations on the geography of disturbance. Can. J. For. Res. 20, 632-641.

SACKs, B. N.; Jaeger, M. M.; Neale, J. C.; MCCullough, D. R., 1999: Territoriality and breeding status of coyotes relative to sheep predation. J. Wildl. Manage. 63, 593-605.

SAETHER, B. E.; ANDERSEN, R., 1996: Ecological correlates of regional variation in life history of the moose Alces alces. Ecology 77, 1493-1500.

SANDELL, M., 1989: The mating tactics and spacing patterns of solitary carnivores. In: GITTLEMAN, J. L. (ed.), Carnivore behavior, ecology, and evolution. Ithaca, New York: Comstock Publ. Associates, pp. 164-182.

SChaEfer, J. A.; Vertch, A. M.; HaRrington, F. H.; Brown, W. K. et al., 1999: Demography of decline of the Red Wine Mountain caribou herd. J. Wildl. Manage. 63, 580-587.

SCHMIDT, J. L.; GLLBERT, D. L., 1978: Big Game of North America. Harrisburg, PA: Stackpole Books. 494 pp. 
SCHNEIDER, E. D., 1988: Thermodynamics, ecological succession, and natural selection: a common thread. In: WEBER, B. H.; DEPEW, D. J.; SMTTH, J. D. (eds.), Entropy, Information, and Evolution. Cambridge, Mass.: MIT Press, pp. 107-138.

SCHNEIDER, E. D.; KAY, J.J., 1994: Complexity and thermodynamics: towards a new ecology. Futures $24,626-647$.

SCHWARTZ, C. C.; FRANZMANN, A. W., 1991: Interrelationship of black bears to moose and forest succesion in northern coniferous forest. Wildl. Monogr. 113, 58.

SeIdenstickeR, J. C.; Hornocker, M. G.; WiLES, W. V.; Messick, J. P., 1973: Mountain lion social organization in the Idaho primitive area. Wildl. Monogr. 35, 1-60.

SHANAHAN, T., 2000: Evolutionary progress? BioScience 50, $451-459$.

SINCLAIR, A. R. E., 1997: Carrying capacity and the overabundance of deer. In: MCSHEA, W. J.; UNDERwOOD, H. B.; RAPPOLE, J. H. (eds.), The science of overabundance: deer ecology and population management. Washington, USA: Smithsonian Inst. Press, pp. 380-394.

Singer, F. J.; HARTing, A.; SYMONDS, K. K.; CoughenOUR, M. B., 1997: Density dependence, compensation, and environmental effects on elk calf mortality in Yellowstone National park. J. Wildl. Manage. 61, 12-25.

Singer, F. J.; SwIFT, D. M.; Coughenour, M. B.; VARL.ey, J. D., 1798: Thunder on the Yellowstone revisited: an assessment of management of native ungulates by natural regulation, 1968-1993. Wildl. Soc. Bull. 26, 375-390.

SKOGLAND, T., 1991: Ungulate foraging strategies: optimization for avoiding predation or competition for limiting resources. In: BOBEK, B.; PERZANOWSKI, K.; REGELIN, W. L. (eds.), Global trends in wildlife management. Krakow, Poland: Swiat Press, Vol. 1, pp. 161-167.

SLOUGH, B. G.; MOWAT, G., 1996: Lynx population dynamics in an untrapped refugium. J. Wildl. Manage. 60, 946-961.

SMITH, B. L.; ROBBins, R. L., 1994: Migrations and management of the Jackson elk herd. U. S. Dept. Interior, Nat. Biol. Survey, Resources Publ. 199,61.

SMITH-FLUECK, J. M.; FLUECK, W. T., 1996: Natural mortality patterns in an endangered Andean cervid population. Third Ann. Conf. The Wildl. Soc.: 154-155.

SMITH-FLUECK, J. M.; FLUECK, W. T., 1997: Revelamiento de una población de huemul en la provincia de Río Negro, Argentina. J. Neotrop. Mammal. 4, 25-33.

Solomon, M. E, 1949: The natural control of animal populations. J. Anim. Ecol. 18, 1-32.

SOULE, M. E; TERBORGH, J., 1999: Conserving nature at regional and continental scales - a scientific program for North America. BioScience 49, 809-817.

SPREADBURY, B. R.; MUSIL, K.; MUSIL, J.; KAISNER, C. et al., 1996: Cougar population characteristics in southeastern British Columbia. J. Wildl. Manage. 60, 962-969.

STEPANOV, Y. V.; POLE, S. B., 1996: Numbers of wolves and the attitude towards them in Kazakhstan during recent decades. J. Wildl. Res. 1, 321-322.

STROMAYER, K. A.; WARREN, R. J., 1997: Are overabundant deer herds in the eastern United States creating alternate stable states in forest plant communitites? Wildl. Soc. Bull. 25, 227-234.

TAYLOR, R. J; PEKINS, P. J, 1991: Territory boundary avoidance as a stabilizing factor in wolf-deer interactions. Theoretical Pop. Biol. 39, 115-128.

TERBORGH, J., 1988: The big things that run the world - a sequel to E. O. Wilson. Conserv. Biol. 2, $402-403$.

THE RED DEER COMMISSION, 1989: Natural mortality in red deer stocks in Scorland. Deer 7, 545-546.

THURBer, J. M.; PETERSON, R. O., 1991: Changes in body size associated with range expansion in the coyote (Canis latrans). J. Mamm. 72, 750-755.

TomialojC, L., 1991: Characteristics of old growth in the Bialowieza Forest, Poland. Natural Areas J. 11, 7-18.

ULANOWICZ, R. E., 1996: The propensities of evolving systems. In: KHALIL, E. L.; BOULDIGN, K. E. (eds.), Evolution, order and complexity. London: Routledge, pp. 217-233.

ULANOwICZ, R. E., 1997; Ecology, the ascending perspective. New York: Columbia Univ. Press. pp. 1-224.

ULANOWICZ, R. E., 1999: Life after Newton: an ecological metaphysic. BioSystems 50, 127-142.

ULANOWICZ, R. E.; ABARCA-ARENAS, L. G., 1997: An informational synthesis of ecosystem structure and function. Ecol. Modeling 95, 1-10.

VAN VALKENBURGH, B., 1995: Tracking ecology over geological time: evolution within guilds of vertebrates. Trends Ecol. Evol. 10, 71-75. 
VAN WIEREN, S. E., 1989: The management of populations of large mammals. In: SPELLERBERG, I. F; GoldSMITH, F. B.; MORRIs, M. G. (eds.), The scientific management of temperate communitites for conservation. London: Blackwell Scientific Publisher, pp. 103-127.

VerTCH, A. M.; KRIZAN, P. K., 1996: Black bear predation on vertebrates in northern Labrador. J. Wildl. Res. 1, 193-194.

VERMEIj, G. J, 1994: The evolutionary interaction among species: selection, escalation, and coevolution. Ann. Rev. Ecol. System. 25, 219-236.

WASER, P. M., 1996: Patterns and consequences of dispersal in gregarious carnivores. In: GITTLEMAN, J. L. (ed.), Carnivore behavior, ecology, and evolution. Ithaca, New York: Comstock Publ. Associates, pp. 267-295.

Weber, B. H.; DEPEW, D. J.; DYKe, C.; SALTHE, S. N. et al., 1989: Evolution in thermodynamic perspective: an ecological approach. Biology and Philosophy 4, 373-405.

WERDELIN, L., 1996: Carnivoran ecomorphology: a phylogenetic perspective. In: GITLEMAN, J. L. (ed.), Carnivore behavior, ecology, and evolution. Ithaca, New York: Comstock Publ. Associates, pp. 582-624.

WHITE, C. A.; BARTMANN, C. E.; KAY, C. E., 1998: Aspen, elk, and fire in the Rocky Mountain national parks of North America. Wildl. Soc. Bull. 26, 449-462.

WHITE, G. C.; BARTMANN, R. M., 1997: Density dependence in deer populations. In: MCSHEA, W. J.; UNDERWOOD, H. B.; RAPPOLE, J. H. (eds.), The science of overabundance: deer ecology and population management. Washington, USA: Smithsonian Inst. Press, pp. 120-135.

WHITMAN, J. S.; BALLARD, W. B.; GARDNER, C. L., 1986: Home range and habitat use by wolverines in southcentral Alaska. J. Wildl. Manage. 50, 460-463.

WHITTAKER, D. G.; LINDZEY, F. G., 1999: Effect of coyote predation on early fawn survival in sympatric deer species. Wildl. Soc. Bull. 27, 256-262.

WIELGUS, R. B.; BUNNELL, F. L., 1994: Sexual segregation and females grizzly bear avoidance of males. J. Wildl. Manage. 58, 405-413.

WILCOX, D. L.; MACCluER, J. W., 1979: Coevolution in predator-prey systems: a saturation kinetic model. Am. Naturalist 113, 163-183.

YeVTIKOV, S. A., 1991: Natural mortality rate in European moose. In: BOBEK, B.; PerzanOwSKI, K.; REGELIN, W. L. (eds.), Global trends in wildlife management. Krakow, Poland: Swiat Press, Vol. 1, Pp. 653-654.

YOUNG, D. D,; MCCABE, T. R., 1997: Grizzly bear predation rates on caribou calves in northeastern Alaska. J. Wildl. Manage. 61, 1056-1066.

YTREHUS, B.; SKagemo, H.; STUVE, G.; SiverTSEN, T. et al., 1999: Osteoporosis, bone mineralization, and status of selected trace elements in two populations of moose calves in Norway. J. Wildl. Dis. 35, 204-211.

ZhelezNov, N. K., 1992: Ecology of the grey wolf (Canis lupus) on Chukotka. In: BOBEK, B.; Perzanowski, K.; Regelin, W. L. (eds.). Krakow, Poland: Swiat Press, pp. 381-384.

ZHELEZNOV, N. K., 1996: Large predators of the far north-east of Russia. J. Wildl. Res. 1, 112-116.

ZOLLER, H., 1993: Menschliche Nutzung im Unterengadin während vor- und frühgeschichtlicher Zeit. Cratschla (Switzerland) 1, 16-24.

ZOLLER, H.; HAAS, J. N., 1995: War Mitteleuropa ursprünglich eine halboffene Weidelandschaft oder von geschlossenen Wäldern bedeckt? Schweiz. Z. Forstwes. 146, 321-354.

Authors address: W. T. FluECK, DeerLab, C. C. 176, 8400 San Carlos de Bariloche, Argentina, E-mail: deerlab@infovia.com.ar 